\title{
The Dating of Västerhus Cemetery A Contribution to the Study of Christianization in Jämtland
}

\author{
Olof Holm
}

\begin{abstract}
In this article, the author uses different dating methods to try to show that the Västerhus cemetery was established between c. 1125 and 1250 and that it ceased to be used between $c .1375$ and 1500 . This time period is later than the dates proposed previously on the basis of ${ }^{14} \mathrm{C}$ analyses of skeletons from the cemetery. In the author's opinion, the ${ }^{14} \mathrm{C}$ dates are probably misleading on account of reservoir effects. The Västerhus church and cemetery - which yielded one of the best preserved and most well-studied medieval skeletal materials in northern Europe - were thus not established at the time of Jämtland's official Christianization, as earlier claimed, but instead one or a few generations later. The author points out that several other early churches and cemeteries in Jämtland are just as late. Similar gaps in time between the official Christianization and the widespread building of churches are also known from other parts of Scandinavia.
\end{abstract}

Olof Holm, Department of History, Stockholm University, SE-106 91 Stockholm, Sweden.

Key words: ${ }^{14} \mathrm{C}$ dates, arm-position typology, Christianization, churchbuilding, Jämtland, medieval cemetery, reservoir effects, Västerhus

\section{THE AIM OF THE INVESTIGATION'}

Västerhus, on the island of Frösö in Jämtland, is a classic site within Nordic medieval archaeology and human osteology. At this site, during the years 1947 and 1951-52, a total excavation was undertaken of the ruins of a medieval church and adjacent cemetery. In the excavation the remains of a Romanesque stone church were documented, and the skeletons of more than 150 adults, about 200 children, and seven fetuses were recovered. The documentation and skeletal material were subsequently analysed by Nils-Gustaf Gejvall, who presented his results in 1960 in an internationally acknowledged thesis titled, Westerhus. Medieval Population and Church in the Light of Skeletal Remains. This was the first time in Scandinavia that a medieval cemetery and skeletal material was excavated in its entirety and published scientifically. Other cemeteries have since been excavated, but so far none has yielded a bone material as well preserved and complete as that of Västerhus. The Västerhus cemetery thus holds a unique position,

\footnotetext{
${ }^{1}$ This article is an adaptation of my C-level thesis in archaeology, fall term 2004 (presented 2005) at the Department of Archaeology and Antique History, Stockholm University.
} 
and it still attracts a great deal of attention within research today (see e.g., Jonsson 1999; Alexandersen \& Iregren 2000; Iregren \& Redin 2000; Iregren, Jungner, Räisinen \& Alexandersen 2000; Redin 2000; Iregren 2002).

The dating of the cemetery is, of course, essential for anyone who wants to use the excavation results and skeletal material for a scientific purpose. In this article I will argue for a somewhat later time period for the cemetery than the dates presented in previous research. I will also attempt to relate the establishment of Västerhus Church and its cemetery to the process of Christianization and the formation of a church organisation in Jämtland. ${ }^{2}$

\section{THE DATING OF VÄSTERHUS CEMETERY: PREVIOUS RESEARCH}

In discussions on the dating of the Västerhus cemetery, ${ }^{14} \mathrm{C}$ analyses of human skeletons from the cemetery have played an important role. The first twelve ${ }^{14} \mathrm{C}$ analyses were made already in the mid-1960s (St-1909, 1919, 1923, 2141-2149, cf. table 1). In Gejvall's viewpoint (1968) the results of the analyses supported his earlier hypothesis (1960:129) on the dating, namely that the cemetery was established around 1050-1100 and that it probably ceased to be used in 1350 when the Black Death raged.

Eight new ${ }^{14} \mathrm{C}$ analyses were undertaken in 1999 (Ua-15061-15068) and an additional ten in 2001 (Ua-18298-18307), which means there now is a total of $30{ }^{14} \mathrm{C}$ analyses of just as many skeletons from the cemetery. Several researchers have brought these analyses up for discussion, among others Lars Redin (2000), Ola Kyhlberg and Ulf Strucke (in an appendix to Redin 2000), and most recently Claes-Henric Siven in an article titled, "When was Westerhus churchyard in use?" published in Current Swedish Archaeology 13 (2005). ${ }^{3}$

One problem when dating organic material from the Middle Ages with the radiocarbon method (i.e., the ratio between the decaying ${ }^{14} \mathrm{C}$ isotope and the stable ${ }^{12} \mathrm{C}$ isotope is measured in a sample, and thereafter age is calculated on the basis of the known half-life of ${ }^{14} \mathrm{C}$ ) is, of course, that the margins of error are rather wide for calculated ${ }^{14} \mathrm{C}$ dates. The ${ }^{14} \mathrm{C}$ dates from the Västerhus samples have after calibration (i.e., the dates are adjusted in view of the fact that the amount of ${ }^{14} \mathrm{C}$ in the atmosphere has varied over time) error intervals of at least 140 years and at the most 350 years when these are expressed with $2 \sigma$ precision (i.e., the correct results are with $95.4 \%$ confidence calculated to be within the given intervals), see table $1 .{ }^{4}$ When these straggly analysis results are used as a

\footnotetext{
${ }^{2}$ For more recent research, see i.a. Brink 1996a; 1996b; Gräslund 1996; Nilsson 1996a; Sandnes 1996; Vikstrand 1996; Williams 1996; Holm 2001; Welinder 2003

${ }^{3}$ The spelling used by Siven and other researchers - Westerhus - is outdated. Västerhus is a living community-name, used on maps, road signs and in everyday speech, and it should be spelled according to the accepted rules for language usage.

${ }^{4}$ Note that the calibrations in table 1 are done with the help of the calibration programme OxCal $v 3.10$, which is based on the new series of atmospheric data published in Reimer et al. 2004. The calibrations in Redin, Kyhlberg/Strucke and Siven, as well as those in Jonsson (1996:6), were done with older calibration tools.
} 
basis for dating, there is a risk that the cemetery's time of use will be overestimated.

To avoid the problem of overestimating, Kyhlberg/Strucke as well as Siven have tried to combine the various ${ }^{14} \mathrm{C}$ dates. They use different methods in their attempts. Kyhlberg and Strucke set up a series of quartile values based on calibrated ${ }^{14} \mathrm{C}$ dates with $2 \sigma$ confidence interval. They then calculate the first and third quartiles for the new series and use these values to estimate the cemetery's initial year and terminal year. Siven carries out a so-called maximum-likelihood-estimate and adjusts obtained values for bias after having run simulations. This results in point and interval estimates of the cemetery's initial and terminal years.

With their method, Kyhlberg and Strucke estimated the initial year of the cemetery to 1098 and the terminal year to 1292. They did not, however, have access to the ten ${ }^{14} \mathrm{C}$ analyses from 2001 . Had they been able to take these analyses into account, they would according to my estimates have reached roughly the same conclusion, namely that the cemetery was in use c. 1100-1300. It appears that their method leads to an underestimate of the cemetery's time of use. What speaks for this is, among other things, that the three youngest ${ }^{14} \mathrm{C}$ dates now available have been calibrated to such late time intervals as 1260-1420, 12701420 and 1290-1430, respectively (see table 1). Kyhlberg's and Strucke's method has also been criticized by Siven (2005:166).

Siven, using his own method and on the basis of the entire series of $30{ }^{14} \mathrm{C}$ dates, has estimated the initial year of the cemetery to 1073 and the terminal year to 1356 . These point estimates are surrounded by confidence intervals. The initial year, according to Siven, is with $95.4 \%$ confidence between 1029 and 1130 , and the terminal year with equally great confidence between 1327 and 1407 .

Siven $\left(2005: 165,170 \mathrm{f}\right.$.) makes two source-critical comments on the ${ }^{14} \mathrm{C}$ series from the Västerhus cemetery. Firstly, he points out that only 30 of the 364 registered individuals in the cemetery have been radiocarbon dated, and that "additional ${ }^{14} \mathrm{C}$-dated individuals might lead to a longer estimated period of use of the churchyard". 5 At the same time he notes, as a positive aspect, that since the selection of graves for ${ }^{14} \mathrm{C}$ samples was done with respect to the stratigraphy in the cemetery, both relatively early and relatively late graves are included in the ${ }^{14} \mathrm{C}$ series. This indicates that additional ${ }^{14} \mathrm{C}$ dates would hardly result in a significantly longer estimated period of use.

Secondly, Siven points out that calibrated ${ }^{14} \mathrm{C}$ dates of human bones can indicate that the bones are older than they really are, due to what is called accumulation or the reservoir effect. Here, Siven is referring to the kind of reservoir effect that occurs when people have consumed marine foodstuffs. In the sea there is a deficiency of ${ }^{14} \mathrm{C}$ in comparison to the contemporaneous atmosphere, and marine organisms thus exhibit an apparent ${ }^{14} \mathrm{C}$ age, the so-called

\footnotetext{
${ }^{5}$ The skeleton from grave 70 could yield an even later ${ }^{14} \mathrm{C}$ date than the dates hitherto obtained. Grave 70 overlay namely grave 69 (see Gejvall $1960 \mathrm{pl}$. 10 and grave plan), whose skeleton has the next youngest ${ }^{14} \mathrm{C}$ date obtained thus far (see table 1).
} 
Table $1 .{ }^{14} \mathrm{C}$-dated skeletons from the Västerhus cemetery

\begin{tabular}{|c|c|c|c|c|c|c|}
\hline $\begin{array}{l}\text { Grave/ } \\
\text { individ. } \\
\#\end{array}$ & $\begin{array}{l}{ }^{14} \mathrm{C} \text { age }(\mathrm{yr} \mathrm{BP}) \\
\text { laboratory no. }\end{array}$ & $\begin{array}{l}\text { Calibrated } \\
{ }^{14} \mathrm{C} \text { age (cal. } \\
\text { yrs AD), } 2 \sigma\end{array}$ & $\begin{array}{l}\delta^{13} \mathrm{C} \% \\
\mathrm{PDB}\end{array}$ & $\begin{array}{l}\text { Arm- } \\
\text { position } \\
\text { type }^{1}\end{array}$ & $\begin{array}{l}\text { Relative strati- } \\
\text { graphic dating }\end{array}$ & $\begin{array}{l}\text { Individual's sex } \\
(\mathrm{M} / \mathrm{F}) \text { and age } \\
\text { according to } \\
\text { osteological } \\
\text { analysis }\end{array}$ \\
\hline 4 & $1010 \pm 55 ;$ Ua- 15062 & $890-1160$ & -21.2 & A & $\begin{array}{l}\text { Older than } \# 3 \text {; } \\
\text { younger than the } \\
\text { church's oldest part }{ }^{2}\end{array}$ & M, 50-60 yrs \\
\hline 171 & $1010 \pm 65 ;$ St-2144 & $880-1180$ & & & $\begin{array}{l}\text { Older than } \# 172 \\
\text { (type C) and prob. } \\
\# 175 \text { (type D) }\end{array}$ & $\mathrm{M}, 18-20 \mathrm{yrs}$ \\
\hline 1 & $950 \pm 55 ; \mathrm{Ua}-15061$ & $990-1210$ & -20.4 & B & $\begin{array}{l}\text { Younger than the } \\
\text { tower's foundation } \\
\text { walls }^{3} \text { and } \# 2\end{array}$ & F, 20-25 yrs \\
\hline To i & $945 \pm 70 ;$ Ua- 15068 & $970-1260$ & -22.8 & & & $6-9 \operatorname{mos}$ \\
\hline 52 & $935 \pm 70 ;$ Ua- 18300 & $980-1260$ & -21.5 & $\mathrm{D}$ & $\begin{array}{l}\text { Older than } \# 51 \\
\text { (type } \mathrm{C},{ }^{14} \mathrm{C} \text {-dat. } \\
725 \pm 70 \mathrm{BP} \text { ) }\end{array}$ & $\mathrm{F}, 40-50 \mathrm{yrs}$ \\
\hline 223 & $900 \pm 50 ; \mathrm{Ua}-18306$ & $1020-1230$ & -21.2 & & & $\mathrm{M}, 40-50 \mathrm{yrs}$ \\
\hline 206 & $890 \pm 70 ; \mathrm{Ua}-15066$ & $1020-1260$ & -22.4 & & $\begin{array}{l}\text { Older than the } \\
\text { nave's west wall }\end{array}$ & $\mathrm{F},>60 \mathrm{yrs}$ \\
\hline E $89 \mathrm{~d}$ & $890 \pm 55 ;$ Ua- 15063 & $1020-1260$ & -20.4 & & & $8 \mathrm{yrs}$ \\
\hline "555 A"4 & $880 \pm 65 ;$ St- 1909 & $1020-1260$ & & & & \\
\hline 130 & $875 \pm 55 ;$ Ua- 18303 & $1030-1260$ & -21.6 & & & $4-5$ yrs \\
\hline 91 & $875 \pm 65 ;$ St- 1919 & $1030-1270$ & & $\mathrm{C}$ & & $\mathrm{F}, 40-50 \mathrm{yrs}$ \\
\hline 227 & $860 \pm 55 ;$ Ua- 18307 & $1030-1270$ & -20.7 & & & $F, 50-60$ yrs \\
\hline E $89 \mathrm{~g}$ & $860 \pm 55 ; \mathrm{Ua}-15064$ & $1030-1270$ & -21.2 & & & $2-3$ yrs \\
\hline 123 & $830 \pm 50 ;$ Ua- 18302 & $1040-1280$ & -21.2 & & & $2 \frac{1}{2}-3$ yrs \\
\hline 32 & $830 \pm 60 ;$ St-2149 & $1040-1280$ & & & & F, 50-60 yrs \\
\hline To a & $830 \pm 65 ;$ Ua- 15067 & $1040-1290$ & -21.4 & & & $1-2$ yrs \\
\hline 134 & $820 \pm 55 ; \mathrm{Ua}-18304$ & $1040-1290$ & -21.4 & & & $M, 40-50$ yrs \\
\hline 5 & $815 \pm 65 ;$ Ua- 18298 & $1040-1290$ & -19.4 & $\mathrm{D}$ & & $\mathrm{M}, 40-50$ yrs \\
\hline$" 555 \mathrm{~B} " 5$ & $775 \pm 70 ;$ St -1923 & $1040-1390$ & & & & \\
\hline 9 & $765 \pm 65 ;$ St -2147 & $1050-1390$ & & & Younger than $\# 8^{6}$ & M, 13-14 yrs \\
\hline 96 & $765 \pm 55 ; \mathrm{Ua}-15065$ & $1150-1390$ & -21.0 & $\mathrm{C}$ & & F, 30-35 yrs \\
\hline 177 & $750 \pm 65 ;$ St-2148 & $1150-1400$ & & & Younger than $\# 178$ & $9-10 \mathrm{yrs}$ \\
\hline 54 & $740(?) \pm 65 ;$ St $-2141^{7}$ & $1150-1400$ & & $\mathrm{C}$ & Younger than \#56 & $F, 35-40$ yrs \\
\hline 117 & $740 \pm 60 ;$ St-2146 & $1160-1400$ & & $\mathrm{C}$ & & M, 30-35 yrs \\
\hline 51 & $725 \pm 70 ;$ Ua-18299 & $1160-1400$ & -21.0 & $\mathrm{C}$ & $\begin{array}{l}\text { Younger than } \# 50 \text {, } \\
52 \text { (type } \mathrm{D},{ }^{14} \mathrm{C} \text {-dat. } \\
935 \pm 70 \text { ) }\end{array}$ & $F, 50-60$ yrs \\
\hline
\end{tabular}




\begin{tabular}{|c|c|c|c|c|c|}
\hline $680 \pm 60 ; \mathrm{St}-2145$ & $1220-1410$ & & $\mathrm{C}$ & & $\mathrm{M}, 40-50$ yrs \\
\hline $650 \pm 65 ;$ St-2142 & $1260-1420$ & & & & F, 30-35 yrs \\
\hline $645 \pm 85 ;$ St-2143 & $1220-1440$ & & $\mathrm{D}$ & & $\mathrm{M}, 40-50$ yrs \\
\hline $620 \pm 60 ;$ Ua- 18301 & $1270-1420$ & -21.5 & $\mathrm{C}$ & $\begin{array}{l}\text { Younger than \#68 } \\
\text { (type C); older than } \\
\# 70 \text { (type D) }\end{array}$ & F, 25-30 yrs \\
\hline $580 \pm 55 ;$ Ua- 18305 & $1290-1430$ & -21.2 & $\mathrm{C}$ & $\begin{array}{l}\text { Younger than \#160 } \\
\text { (type C) }\end{array}$ & $\mathrm{M}, 40-50$ yrs \\
\hline
\end{tabular}

${ }^{1}$ According to Redin's typology (Redin 1976). A = the forearms of the deceased are placed alongside the body; $\mathrm{B}=$ the forearms are bent over the pelvis; $\mathrm{C}=$ the forearms are over the body at the waist; $\mathrm{D}=$ the forearms are bent over the ribcage.

${ }^{2}$ To judge by the grave's central position in the nave, at the mid-axis of the church.

${ }^{3}$ To judge by the grave's central position in the tower.

${ }^{4,5}$ The skeletons designated " 555 A" and "555 B" in Engstrand (1967:431) are, according to Gejvall (1968:137), from "a mass grave of some 23 individuals" NE of the church. Cf. Gejvall 1960:28f.

${ }^{6}$ Stratigraphically, grave 9 overlay grave 8 according to Gejvall $1960 \mathrm{pl}$. 10. In Gejvall's grave plan, however, grave 8 is incorrectly marked with an unbroken line instead of a broken one (as if grave 9 lay below and was older than grave 8). A similar error in marking is seen in the plan of graves 62 and 64 .

${ }^{7}$ In Engstrand 1967:430 as well as Sellstedt et al. 1967:148, the BP-age is given as " $740 \pm 65$ " but the ADage as "1240" for St-2141. One of these ages must be wrong. Probably the BP-age is correct, while the ADage (which is calculated by subtracting the BP-age's central value from the year 1950) is wrong due to an error in calculation. Gejvall 1968 uses the AD-age 1240 (but calibrates it to 1218). Unfortunately the laboratory documents concerning the relevant ${ }^{14} \mathrm{C}$ analysis are packed away and at present not accessible (according to comm. the author received from Per S. Andersson, director of the Laboratory for Isotope Geology at the Swedish Museum of Natural History, Stockholm, 17/11 2005).

Sources: ${ }^{14} \mathrm{C}$ ages: Engstrand 1967:430f.; Redin 2000 fig. 8; Possnert \& Söderman 2001; $\delta^{13} \mathrm{C}$-values: Iregren et al. 2000 fig. 9; Possnert \& Söderman 2001; osteological sex and age assessments: Gejvall 1960 tab. 22 as well as Alexandersen in Iregren et al. 2000 fig. 9 (E $89 \mathrm{~d}$, E $89 \mathrm{~g}$ ) and Iregren ibid. (To a). Calibrations after Reimer et al. 2004, done by the author with the calibration programme OxCal v3.10 (2005). Arm positions were determined by $L$. Redin (communicated to the author in letters 13/9 and 19/9 2005 ) and confirmed by the author after examining field photos in ATA and in Gejvall $1960 \mathrm{pl}$. 4. Relative stratigraphical datings are based on information in Gejvall 1960 pl. 10 and grave plan (fold-out). 
reservoir age, which in the north Atlantic is about 400 years (see e.g., Lanting \& van der Plicht 1998:153). In principle, however, the percentage of marine food in the diet can be estimated with the aid of the $\delta^{13} \mathrm{C}$ value in the skeleton and in this way the ${ }^{14} \mathrm{C}$ dates can be corrected. Siven maintains that, with regard to the analysed Västerhus individuals, the $\delta^{13} \mathrm{C}$ levels in the skeletons are low, between -22.8 and $-19.4 \%$ (see table 1 ), which indicates a small intake of marine food (cf. Iregren et al. 2000:190). Siven therefore believes that, "the accumulation problem is of smaller significance than for a coastal population".

In practice Siven assumes that the ${ }^{14} \mathrm{C}$ series in its entirety reflects the cemetery's total time of use rather well. Thus he ends his article by drawing the following conclusions on the dating of the cemetery:

The churchyard came into use in connection with or not long after the introduction of Christianity in the Swedish province of Jämtland. The adoption of Christianity in Jämtland took place sometime in the middle of the eleventh century as indicated by a runic stone at Frösön [...]. Considering the broad confidence interval, the estimated terminal year conforms well to the occurrence of the Black Death. (Siven 2005:177)

The only researcher in recent years to try a different dating method than ${ }^{14} \mathrm{C}$ analysis is Lars Redin. In an article from 2000, he maintains that an analysis of the occurrence of different types of arm positions among the buried in the Västerhus cemetery indicates that the cemetery was in use from the $13^{\text {th }}$ to the $15^{\text {th }}$ century. This late dating conflicts with the ${ }^{14} \mathrm{C}$ dates. Redin finds the discrepancy problematic, and he calls for more thorough research: "A more thorough test of the ${ }^{14} \mathrm{C}$ datings as compared the datings suggested by the arm positions is necessary." In spite of Redin's challenge, the arm-position chronology is met with silence by Siven in his article.

\section{THE RELIABILITY OF THE ${ }^{14} \mathrm{C}$ DATES}

As mentioned above, Siven considers that the problem of the reservoir effect is of small significance when dealing with the ${ }^{14} \mathrm{C}$ dates of the Västerhus skeletons. However, Siven only touches upon the reservoir effect that comes from consumption of marine food. He then overlooks that also consumption of food from fresh waters and in particular from those containing dissolved old carbonates may result in a reservoir effect, which may make the human bones appear older than they really are.

In freshwater systems old carbonate deposits, with little or no radiocarbon, may be dissolved by humic acid or interaction with carbon dioxide. When the water taking part in this process is fed into lakes and rivers, the lake or river water will appear old. This special case of the reservoir effect is usually called the hardwater effect. The lake or river water will also appear old if groundwater, without any contact with the atmosphere for hundreds or thousands of years, is fed into the lake or river through wells. Decaying organic matter in the sediment could 
also contribute to the reservoir age of a lake (I. U. Olsson 1983:279, 284f., 1993:219; Lanting \& van der Plicht 1998; Cook et al. 2001, 2002; Fischer \& Heinemeier 2003; cf. Heier-Nielsen et al. 1995). In reality, most lake waters show reservoir effects, and Ingrid U. Olsson (1986:292) has concluded that "the reservoir age of Swedish lakes must be assumed to be $300-400$ years as a first approximation, unless specific reasons can be given for other assumptions". Such a reason could be that some lakes have hard water; the reservoir age is then often much higher (I. U. Olsson 1997:35, 1999; Lanting \& van der Plicht 1998). As an example, the reservoir age of the hard-water lake Säynäjälampi in NE Finland has been estimated to about 2000 years (I. U. Olsson et al. 1983).

The implications of this, in practice, when ${ }^{14} \mathrm{C}$ dating human bones can be illustrated by a few historically known persons whose skeletons were analysed by J. N. Lanting and J. van der Plicht (1996, 1998). Two examples are Hadewig and Willem I, who died in 1167 and 1222 respectively. The ${ }^{14} \mathrm{C}$ ages are 1105 $\pm 45 \mathrm{BP}$ and $1215 \pm 50 \mathrm{BP}$, respectively, which after calibration (in the same way as for the Västerhus skeletons in table 1) fall within the calendar year intervals 810-1020 and 670-950, respectively, when expressed with $2 \sigma$ precision. Here, thus, the age offset caused by the reservoir effect is one or several hundreds of years. Lanting and van der Plicht (1998:161) conclude that this is the result of a combined intake of marine and freshwater fish.

Central Jämtland belongs to the most calcareous areas in Sweden (Fredén 1994:118). Here, the hard-water effect can be assumed to be large in the lakes and running waters. How much fish from these waters, then, can we estimate that the individuals at the Västerhus cemetery had consumed?

In general, fish was an important part of diet before the Reformation in Scandinavia, partly due to the Church's prescriptions for fast days. According to laws in Norway in the Early Middle Ages, during 93 fast days per year it was forbidden to eat meat, and during another 13 it was forbidden to eat meat, eggs and dairy products, but during all the fast days it was permissible to eat fish (Sanmark $2004 \mathrm{ch}$. 6). In well-investigated layers of household waste deposited at Eisåsen in Berg Parish, Jämtland c. 1250-1450 and at Tibrandsholm in Rödön Parish c. 1350-1650, a large amount of fish bones and fish scales were found, deriving from a number of freshwater species: perch, pike, pike-perch, roach, carp, salmons and whitefishes (Hansson et al. 2005:116-122 and lit. cited therein). Many of the preserved, medieval documents from Jämtland deal with fishing rights (Ahnlund 1948:453-464). We know for instance that an historically known Västerhus resident, Sten Öndsson, in 1423 bought a share of the fishing rights to the Rångnoret river in Hammerdal Parish, and that another person, Birgitta Pedersdotter, at the end of the $15^{\text {th }}$ century sold half the fishing rights to Remme in Indalsälven in Fors Parish ( $J H D$ I 175, II 297). ${ }^{6}$ These pieces of information

${ }^{6}$ Rångnoret was famous for its whitefish and Indalsälven in Fors for its salmon. Jämtlandsposten 8/9 1886; Ahnlund 1948:460ff. 
indicate that a not insignificant consumption of freshwater fish occurred among the individuals buried in the Västerhus cemetery. No calculations for the extent of the consumption are currently available, however.

\section{METHOD}

In light of the above, a durable, absolute dating of the Västerhus cemetery should be based primarily on other grounds than the ${ }^{14} \mathrm{C}$ dates currently available. However, the ${ }^{14} \mathrm{C}$ dates can still be used to make cautious estimates of how long the cemetery was in use and also to arrange the different graves in a rough, relative chronology.

Below, an attempt will be made to date the cemetery by means of a combination of archaeological and historical source materials as well as the available ${ }^{14} \mathrm{C}$ dates.

\section{ARCHAEOLOGICAL DATING OF VÄSTERHUS CEMETERY}

Arm positions as a basis for dating

The arm-position typology was developed as a method of dating by Lars Redin (1976) during the analysis of a cemetery in Skanör. Thereafter it was applied and tested on Scandinavian cemetery materials by, among others, Jakob Kieffer-Olsen (1993) and Hanne Dahlerup Koch $(1997,2000)$. The method rests on the observation that different ways of positioning the arms of the deceased in the burial were dominant during different parts of the Middle Ages. Redin distinguished four different types of arm positions: A: the arms alongside the body; B: the hands over the pelvis; $\mathrm{C}$ : the forearms parallel and over the stomach; and $\mathrm{D}$ : the hands over the chest. As a rule, these arm positions dominated one after the other in the burial custom during the Middle Ages, i.e., in the order A-B-C-D (Redin 1976; Tagesson 1988; Kieffer-Olsen 1993; Christophersen \& Walaker Nordeide 1994:104f.; Dahlerup Koch 1997:54ff.; Mollerup 1999:48-64; E. A. Pedersen 2000; Lilja et al. 2001:39f.; Cinthio 2002:215ff.; Arcini \& Tagesson 2005:288ff.; Wikström MS; cf. Serning 1982:75, 93; Broberg 1991:73; Skov 1997; Carlsson 1999:19; Jäkärä 2000; Pettersson 2000; Hedvall 2003:109f.; Christensen \& Lynnerup 2004:144ff.; J. N. Nielsen 2004:118). Here it should be noted that, during a period when a certain arm position dominated, even other types could occur sporadically. This applies especially to type $\mathrm{D}$, which often occurs parallel with C (Redin 1976:153f., 179; Kieffer-Olsen 1993:76ff.).

As a dating method, the arm-position typology is mainly suited to and foremost tested on free-lying adult graves. Concentrations of several skeletons in one and the same burial context are not suitable for this method since the original arm positions have presumably been disturbed. Children's arm positions also appear

\footnotetext{
${ }^{7}$ Unlike marine fish, freshwater fish has almost the same mean value of $\delta^{13} \mathrm{C}$ as terrestrial food (Lanting \& van der Plicht 1998 table 3). Hence, the $\delta^{13} \mathrm{C}$ values of the Västerhus individuals in table 1 are of no help in estimating the ratio between freshwater fish and terrestrial food in the diet. $\delta^{15} \mathrm{~N}$ values would have been of much more help since $\delta^{15} \mathrm{~N}$ is far more positive in fish than in terrestrial food (cf. Cook et al. 2002), but unfortunately no $\delta^{15} \mathrm{~N}$ analyses have been published yet on the Västerhus skeletons.
} 
to be less suitable for the method, as there is evidence that one did not always arrange children's arms in the same manner as adults' arms during medieval burials (Kieffer-Olsen 1993:75; Mollerup 1999:55).

At the Västerhus cemetery, 117 separately lying, adult graves have been documented, that is, graves with individuals from the age group juvenis (c. 1420 years) and older (Gejvall 1960). Of these 117 adult graves, 57 (49\%) could be determined as to the arm position with the help of preserved photographs from the excavation of the cemetery (in ATA) ${ }^{8}$ Most of the remaining, separately lying, adult graves in the cemetery are not documented with preserved photographs and can therefore not be typologically determined. Of the 57 determined graves, $1(2 \%)$ is of type $\mathrm{A}, 11(19 \%)$ are of type $\mathrm{B}, 33(58 \%)$ are of type $\mathrm{C}$, and $12(21 \%)$ belong to type $\mathrm{D} .{ }^{9}$

For some of these graves, the stratigraphic relationships (see Gejvall $1960 \mathrm{pl}$. 10 and grave plan) make it possible to determine the internal relative chronology of the graves. Redin states $(2000: 165)$ that in three cases graves of type B are older than $\mathrm{C}$-graves, and that some $\mathrm{C}$-graves can be younger than $\mathrm{D}$-graves. During renewed examination, I, too, found the order sequence $\mathrm{B}-\mathrm{C}$ in three stratigraphic relationships (graves 46-45, 48-47, 164-165), whereas evidence for the reversed order sequence is absent. I have identified the sequence $\mathrm{C}-\mathrm{C}-\mathrm{D}$ in one case (6869-70) and the sequence $\mathrm{C}-\mathrm{C}$ in another two cases (63-62, 160-159). In addition, I have found two cases where a D-grave is older than a C-grave $(52-51,84$ 83). ${ }^{10}$ Several of the type-determined adult graves can also be arranged in a rough relative chronology by means of the $30{ }^{14} \mathrm{C}$ dates now available. Even though the relative order sequence is only approximate due to the inexactitude ${ }^{11}$ of the ${ }^{14} \mathrm{C}$ dates, we can still distinguish a pattern (cf. Redin 2000:168): type A occurs earliest, thereafter $\mathrm{B}$, and thereafter $\mathrm{C}$ and $\mathrm{D}$ simultaneously (see table 1). On the whole the stratigraphy and the ${ }^{14} \mathrm{C}$ dates give evidence that the relative order sequence of the arm positions is $\mathrm{A}-\mathrm{B}-\mathrm{C} / \mathrm{D}$. The relative arm-position chronology at the Västerhus cemetery thus corresponds well to conditions described in other parts of Scandinavia.

\footnotetext{
${ }^{8}$ Concerning this photographic material and its origin, see Redin 2000:158-163.

${ }^{9} \mathrm{~A}$ : grave 4; B: 1, 37, 46, 48, 79, 80, 82, 85, 155, 162, 164; C: 24, 36, 40, 45, 47, 51, 53, 54, 60, 62, 63, 66, $68,69,71,83,91,96,105,115$ a $, 117,120,153,159,160,165,172,181,182,189,194,202,226$; D: 5 , $52,70,73,76,84,87,104,122,142,175,190$. Other typologically determined graves (i.e., children's graves or graves included in grave concentrations) at the cemetery are: B: 81, 100, 141, 212; C: 55 a, $72 \mathrm{a}$, $74,108,109 \mathrm{a}$ (?) (alternatively a D-grave), 112,167 b as well as one of the graves $89 \mathrm{a}, \mathrm{b}, \mathrm{c}, \mathrm{d}$ or e. - The typological determinations were done by L. Redin (compiled in letters to the author $13 / 9$ and 19/9 2005) and were confirmed by the author after examination of the photographic material.

${ }^{10}$ The sequence $\mathrm{D}-\mathrm{C}$ is also seen in the stratigraphic relation $73-72 \mathrm{a}$, where the younger skeleton ( $72 \mathrm{a}$ ) belongs to a concentration of three skeletons in one and the same grave context.

${ }^{11}$ In light of the stone church's architectural history (see the following), it is clear that e.g. grave 206, situated under the west wall of the nave, must be older than grave 1 which is centrally situated in the west tower, even though the skeleton in the former grave is ${ }^{14} \mathrm{C}$-dated to $890 \pm 70 \mathrm{BP}$ and the skeleton in the latter to $950 \pm$ $55 \mathrm{BP}$.
} 
It is interesting that more than three fourths of all the typologically determined, separately lying, adult graves in the Västerhus cemetery are C- and D-graves, while only less than one fourth are A- or B-graves (of which only one is an Agrave). Can we therefore conclude that the cemetery was mainly in use during the period when the arm positions $\mathrm{C}$ and D dominated in the burial custom?

One could object to such a conclusion if there was reason to suspect that the representativeness of the typologically determined material was insufficient. In line with Redin $(2000: 163,166)$, however, I believe that the representativeness is good. As mentioned above, $49 \%$ of the total amount of the separately lying, adult graves has been identified as to type. Of the typologically determined graves that can be stratigraphically related to other graves, 19 are older and 19 are younger than other graves. ${ }^{12}$ This even distribution supports the notion that older as well as younger graves in the cemetery are well represented in the typologically determined material.

Another objection would exist if there were grounds to believe that the burial frequency at the cemetery increased markedly over time. If this were the case, it would explain why the late types of arm positions are so common at the cemetery. The compilation of ${ }^{14} \mathrm{C}$ dates in table 1 gives an opportunity to judge the situation. Of the graves that are included in the ${ }^{14} \mathrm{C}$ series and that show a stratigraphic relation to other graves, four are older than other graves and seven are younger. This indicates that younger graves in the cemetery hardly are underrepresented in the ${ }^{14} \mathrm{C}$ series. If we look at the distribution of the uncalibrated ${ }^{14} \mathrm{C}$ dates' central values, we find that $18(60 \%)$ lie in the interval 1010-795 BP (roughly corresponding to the first half of the cemetery's period of use) but only $12(40 \%)$ in the interval 795-580 BP (corresponding to the second half). This distribution contradicts the notion that the burial frequency is higher during the second half of the cemetery's total time of use than it is during the first half. Instead the tendency is the opposite: the burials become less frequent toward the end of the cemetery's time of use.

Yet another objection is worth considering in this connection. The two A- and $\mathrm{B}$-graves that were ${ }^{14} \mathrm{C}$-analysed have yielded dates that are close to each other in time in the cemetery's oldest phase; on the other hand, eleven of the C- and Dgraves have dates that are younger than the A- and B-graves, but are still scattered across the greater part of the cemetery's total time of use. Consequently, the dates of three of the eleven $\mathrm{C}$ - and D-graves $(935 \pm 70,875 \pm 65$ and $815 \pm 65, \mathrm{BP}$, resp.) lie closer to the oldest date in the ${ }^{14} \mathrm{C}$ series $(1010 \pm 55 \mathrm{BP})$ than to the youngest $(580 \pm 55 \mathrm{BP})$.

In view of the above, I am inclined to draw the conclusion that the Västerhus cemetery was established during a time when arm position A was already being abandoned in the burial custom (cf. Redin 2000:166). The earliest phase in the

${ }_{12}^{12}$ Older than other graves: 4, 46, 48, 52, 62, 63, 68, 69, 73, 76, 84, 87, 115 a, 142, 160, 162, 164, 175, 202. Younger than other graves: 1, 36, 37, 45, 46, 47, 51, 54, 62, 69, 70, 76, 83, 159, 165, 172, 175, 190, 194. 
cemetery's time of use occurred during the period when type B dominated in the burial custom. However, this phase represents only a small part of the total time of use of the cemetery. The greater part of the cemetery's time of use occurred instead during the period when arm positions $\mathrm{C}$ and $\mathrm{D}$ dominated in the burial custom. At what time point, then, can we assume that $\mathrm{C}$ and $\mathrm{D}$ became dominant?

At the Olavskirken cemetery in Trondheim, which is partially excavated, the entire series of arm positions is represented, and here it has been possible to establish a stratigraphy in relation to the surrounding buildings and thereby set up an absolute chronology. Here, the $\mathrm{C}$-graves begin to dominate over the $\mathrm{B}$ graves in the burial custom before c. 1275, and at the same time a rather large number of D-graves begin to appear (Christophersen \& Walaker Nordeide 1994: 105). Österlövsta's old church in northern Uppland is, partly on the basis of numismatic evidence, assumed to have come into use at the end of the $13^{\text {th }}$ century (Broberg 1990:81f.). In its cemetery only C- and D-graves were found (KiefferOlsen 1993:76 with ref. to an unpubl. report by M. Vretemark 1981). However, here the number of excavated and typologically determined graves was small (7 graves, thereof $6 \mathrm{C}$ and $1 \mathrm{D}$ ). In an expanded part of the Peterskirken cemetery in Tønsberg, which presumably was established after the start of the $14^{\text {th }}$ century, about 250 determinable graves were found, and with the exception of two Bgraves all of them were C- or D-graves. The dating of the expanded area was based on pottery found in the underlying, profane layers (Blohmé \& Runeby 1986). At the Trinitatis and St. Stefan cemeteries in Lund, all the types A-D occur, and here the shift from the dominance of $\mathrm{B}$ to that of $\mathrm{C}$ takes place around the turn of the $13^{\text {th }}$ to the $14^{\text {th }}$ century (Mårtensson 1980:116ff.; Cinthio 2002:217; cf. Dahlerup Koch 2000:127). The St. Nicolai cemetery in Holbæk on Zealand also has yielded the entire series $\mathrm{A}-\mathrm{D}$, and in this cemetery the corresponding shift takes place in the $14^{\text {th }}$ century (Dahlerup Koch 1997:55). All in all, these examples indicate that the transition from $\mathrm{B}$ to $\mathrm{C}$ as the dominant arm position in the Scandinavian burial custom occurred mainly in the period 1250-1350, with some variation among the different cemeteries. ${ }^{13}$

With regard to the Västerhus cemetery, if we assume that arm positions $\mathrm{C}$ and $\mathrm{D}$ became dominant around the year 1250, and that a greater part of the cemetery's total time of use lies after that time point, then the cemetery must have been established later than the mid- $11^{\text {th }}$ century or its second half, and been in use longer than the mid-14 $14^{\text {th }}$ century. (These are the time points Siven reckons with when he concludes, on the basis of the ${ }^{14} \mathrm{C}$ dates, that the cemetery was established in connection with, or just after, the introduction of Christianity in Jämtland and abandoned around the time of the Black Death, see above.) If we assume a later date in the interval 1250-1350 for the above-mentioned shift, the church's time

\footnotetext{
${ }^{13}$ This dating implies a modification of the dating proposed by Kieffer-Olsen (1993:78). He asserts that the transition occurred c. 1350, but he does not take into account dates from e.g., Trondheim and Lund. Cf. Dahlerup Koch 2000:127.
} 
of use ought to be dated even later. The arm-position chronology at the Västerhus cemetery thus indicates that the above-discussed ${ }^{14} \mathrm{C}$ dates should be corrected and moved forward in time.

\section{Artefacts as a basis for dating}

Only two artefacts found in graves at the Västerhus cemetery could be dated fairly precisely. ${ }^{14}$ One is a Rex Upsalie bracteate ( $L L$ VIII:1) of silver with a cross in the centre (SHM/KMK 25029:41; Gejvall $1960 \mathrm{pl}$. 29), found in grave 194, $195 \mathrm{a}$, or $195 \mathrm{~b}$ and dated to c. 1235-1250 (see below). The other is a pilgrim's badge of lead from St. Martin in Tours (SHM 25029:1; Gejvall 1960 pl. 28), recovered from grave $200 \mathrm{a}$ and dated by Monica Rydbeck to the second half of the $13^{\text {th }}$ century or the $14^{\text {th }}$ century (Rydbeck 1956:285f; Gejvall 1960:109; L. Andersson 1989:93f., 141, 152).

Only the coin is of interest for the dating discussion at hand. It belongs to a rare group of Svealand coins with the inscription "REX VPSALIE" or suchlike around a central motif that can take the form of a cross (only the example from Västerhus is known), a crown ( 2 ex. are known), or an "A" ( 1 ex. is known). On the basis of the epigraphy and the minting style, these coins have been dated to c. 1235-50. ${ }^{15}$ Unfortunately, due to the unclear stratigraphy it is not certain whether the Rex Upsalie coin from the Västerhus cemetery was buried with one of the individuals in no. 195 a or b (a 40-50 year old man and a 4-5 year old child, respectively) or with the individual in no. 194, which in relation to 195 is a secondary burial (an 18-20 year old man; N. Lagerholm cited in Rasmusson 1952:283). Regardless of the uncertainty, the coin indicates that the cemetery was in use around the mid$13^{\text {th }}$ century or somewhat later. ${ }^{16}$

\section{The stone church as a basis for dating}

The research on Västerhus has generally maintained that the stone church was preceded by a wooden church, even though no concrete traces of such have been found (Berthelson 1952:302ff.; Gejvall 1960:125ff.; Almqvist 1984:218f.; Nilsson 1996a:136; Staecker 2001:211ff.; Welinder 2003:519f.). The argument used in support is that some graves (nos. $205 \mathrm{a}-\mathrm{c}$ and 206-208) lay beneath the nave's west wall and southwest corner (cf. fig. 1). ${ }^{17}$ Thus Christian burials must have

\footnotetext{
${ }^{14}$ A penannular brooch of bronze, found in grave 65 (SHM 25029:4a, Gejvall $1960 \mathrm{pl}$. 29; cf. a stray find of a penannular brooch with identical design from Nørholm Parish in the county of Ålborg, Denmark: NM D446/1993, Højmark Jensen 2005 catalogue no. 32), can probably be dated at a future point in time if brooches of the same type turn up in datable contexts. A pricker of elk bone from grave 90 (SHM 25029:7) can probably be dated with ${ }^{14} \mathrm{C}$ (without risk for reservoir effects).

${ }^{15}$ There are speculations as to whether they could have been minted in connection with the so-called Folkungar revolts in Uppland against the regime at the time, revolts that were quashed at Sparrsätra in 1247 and Herrevadsbro in 1251. Rasmusson 1952, 1970:279; Thordeman 1965; Sjöberg 1986a, 1986b; SML 7:31f.; Holmberg 1995:73.

${ }^{16}$ For the time of circulation of coins in Norrland, see Grundberg \& Jonsson 2004:18.

${ }^{17}$ These graves could not be determined as to type of arm position.
} 


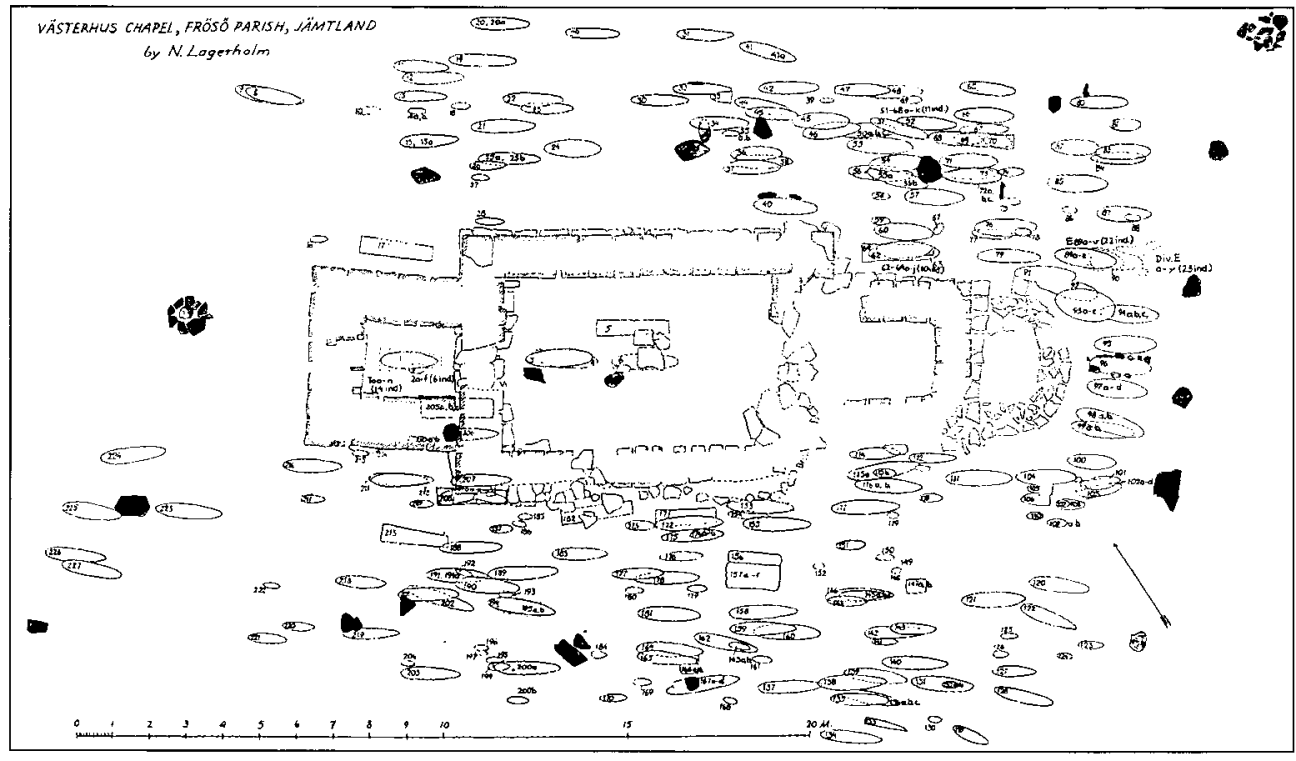

Fig. 1. Nils Lagerholm's plan of graves in the Västerhus cemetery, with Nils-Gustaf Gejvall's grave designations. After Gejvall 1960 (fold-out).

taken place before the walls in the west part of the nave were erected. The general interpretation is that these burials occurred in connection with a wooden church that stood on the same place as the later stone church, with the exception of the southwest corner which lay inside the boundaries of the later church.

Recently Lars Redin (2000:17lf.) has questioned this interpretation. He points out that, if a wooden church had actually existed, not only graves in the west would be overlaid by the stone church's walls but also graves in the east. This is not the case, however. Instead numerous graves have been found outside the east part of the nave, as well as outside the narrow chancel and even outside the semicircular foundation of the apse. The grave-free space in the middle of the cemetery has thus largely the same contours and size as the above-mentioned foundation walls (cf. fig. 1). ${ }^{18}$ Redin therefore draws the conclusion that the stone church was the first church on the site.

I attach great importance to Redin's argument that no graves were disturbed or overlaid by the east foundation walls of the stone church, and neither were there graves situated within these walls. This speaks firmly against the notion that an

${ }^{18}$ Close to the north wall of the nave is a grave-free area. In Redin's opinion (2000:164) it probably arose during removal of graves. However, the archaeological excavations yielded no skeletons there that had been damaged by digging, which should have occurred if graves had been removed. Neither was there evidence for deep, military digging there, as seen in other parts of the cemetery (cf. Gejvall 1960:16f. with pl. 2). Thus, in my opinion the grave-free area must be original. This should be seen in light of the fact that the female graves on the north side of the cemetery were concentrated farther to the east than were the male graves on the south side (cf. Gejvall 1960: pl. 6). Clearly it was considered less appealing to be buried in the most shadowy part of the cemetery immediately $\mathrm{N}$ of the nave, which also was the area where the ground was frozen longest in the spring. - For the graves in the church's nave, see below. 
earlier wooden church with burial rights once stood at the same place as the stone church. It is namely not probable - in fact not possible - that such a wooden church would have the exact same shape and size as the stone church with its narrow chancel and apse foundation. Excavations in other parts of Scandinavia have shown that, in those cases where an early wooden church is known to have stood on the same spot as a later, Romanesque, stone church, the stone church as a rule covers a much larger area than that of the wooden church and furthermore never has the exact same shape in plan (Lidén 1995:128f.; Ahrens 2001:passim). One example is the wooden church which preceded the Romanesque stone church at Mære in Trøndelag, and which was only about one third the size of the latter. This wooden church had burial rights, and during excavation in the 1960s dozens of contemporaneous graves were found directly outside the walls of the wooden church but inside and beneath the foundation walls of the later stone church (Lidén 1969:8, 1999:19-30). ${ }^{19}$

I also attach importance to the absence of any physical traces of a possible wooden church in Västerhus. If a wooden church had been erected at the site in the $11^{\text {th }}$ century, it ought to have been built with roof-supporting posts dug into the ground (forming part of the wall construction or standing inside the walls) and/or with walls dug into the ground. This is how all the $11^{\text {th }}$-century wooden churches in Norway and Sweden, known today, were constructed (Jensenius 2001; Bennett \& Edenheim 1976:27; Vretemark 1998; Hedvall 2003; Alkarp \& Price 2005). Traces of such constructions have good prerequisites for being preserved and detected in archaeological investigations. In the excavation of the Västerhus church ruins, no such traces were found, despite the fact that the excavation leaders were hoping to find remains of a predecessor to the church (cf. Berthelson 1952:301).

If a wooden church had been built at the site in the $12^{\text {th }}$ century, it could have been constructed on a frame of sills resting on a foundation of stones. ${ }^{20}$ In Jämtland, a wooden church of this kind was found under the floor of Mattmar's present-day church. This wooden church was a stave church of a special type, namely a socalled central-mast church, with a large central post dug into the ground in the middle of the nave and with the other posts and walls erected on a frame of sills that rested on a stone foundation. Of the central-mast church in Mattmar, the remains of the stone foundations for the $\mathrm{N}, \mathrm{W}$ and $\mathrm{S}$ walls of the nave were found during an archaeological excavation in 1982. The excavation also revealed the stone-lined post-hole, $1.4 \mathrm{~m}$ deep, in the middle of the nave as well as remains of a $0.4 \mathrm{~m}$ thick post in the post-hole (report by J. Sundström in JLM, Sundström 1989b; Ahrens 2001:252f.; Holm 2003a:47f.). ${ }^{21}$ If a church of similar type had existed in Västerhus, at least the large post-hole should have been discerned

\footnotetext{
${ }^{19}$ For additional examples see Christie 1962, 1966; Skre 1986.

${ }^{20}$ Concerning the dating of such churches, see Anker 2005:33, $91 \mathrm{ff}$.

${ }^{21}$ Furthermore, there were indirect traces of the church in the form of graves outside its walls. See also p. 133 below.
} 
archaeologically - but none such was found. ${ }^{22}$

In the $12^{\text {th }}$ century also other types of wooden churches were built in Norway, which completely lacked constructions dug into the ground (Anker 2005:2735). Traces of such churches can be difficult to detect in archaeological investigations, but can consist of the remains of the stone foundations on which the sills rested, or burnt traces if the church had burnt down. No such traces were observed in Västerhus, however.

Against the background of the above, it does not seem possible that a wooden church with dug-down posts or walls preceded the stone church in Västerhus, nor probable that a wooden church on a frame of sills resting on a stone foundation preceded it.

Further support for the argument that the stone church in Västerhus was the first church with burial rights at the site is the placement of grave no. 4 , the only known A-type grave in the cemetery. This grave had a central position in the west part of the nave and lay beneath a younger grave (cf. fig. 1). As previously mentioned, A-graves often have been found to belong to the oldest graves in investigated cemeteries in Scandinavia, and this can be assumed for Västerhus as well. That grave 4 really is one of the absolute oldest in the Västerhus cemetery is verified by the fact that it has the oldest date in the series of $30{ }^{14} \mathrm{C}$ analyses carried out on skeletons from the site (table 1). This grave was, as said, found central in the nave, exactly at the mid-axis of the stone church. If we imagine that this grave had been established centrally in a wooden church at the site, the stone church must then have been built along the same mid-axis as that of the hypothesized wooden church. In Norway there are examples of second-generation churches built along the same mid-axis as their predecessors, but it is just as usual that the succeeding churches deviate somewhat from this axis (see Jensenius 2001 appendix 1). Concerning grave 4 in Västerhus, the most likely interpretation is that it was established when the stone church was built or at least had begun to be built (cf. Redin 2000:166, 171). The central and exclusive burial place inside the church as well as the grave's high age can indicate that the buried individual, a man 50-60 years old, had contributed to the building of the church and thus earned the privilege of a prestigious burial. ${ }^{23}$ That grave 4 can be identified as one of the absolute oldest in the cemetery and at the same time with great probability can be related to the stone church, makes it less plausible that any graves at all in the cemetery are older than the planning stage of the stone church.

\footnotetext{
${ }^{22}$ One can speculate that when grave 6 was established centrally in the nave of Västerhus Church it damaged the traces of a possible post-hole, but it can hardly have obliterated them. Grave 6 was quite shallow. Gejvall 1960 pl. 10.

${ }^{23}$ Note that an additional three men and an infant were later buried in the nave (cf. fig. 1). Like grave 4, grave 6 - mentioned in the preceding footnote - is situated in the mid-axis of the church, but is not dated. Grave 5 (of type $\mathrm{D}$ ) is ${ }^{14} \mathrm{C}$-dated to the middle phase of the cemetery's time of use (see table 1). Its position $\mathrm{N}$ of grave 6 may indicate it is secondary in relation to this grave. Grave 3 is stratigraphically younger than no. 4 . - For burials in the church, near the sacred altar, see Andrén 2000.
} 
All in all I find the arguments against the existence of a wooden church with burial rights so strong that I have to agree with Redin's conclusion that the stone church in Västerhus was the first church with burial rights at the site.

As an explanation for why some graves came to be overlaid by the nave's west wall and southwest corner, Redin suggests that Christian burials can have occurred 1) in connection to an Iron Age burial-ground before a church was planned, 2) at a consecrated cemetery before the church was built and the church's plan was devised in detail, or 3) before the west part of the church was constructed but after other parts had been built. I find the first alternative less probable. In my view the distribution of graves in the cemetery, with a large empty space in the middle for the church, as well as the near consistent gender separation with women buried north and men south of the church (Gejvall 1960:43f., pl. 6, Alexandersen \& Iregren 2000:213f.), presupposes at least the plans to build a stone church. ${ }^{24}$

The second alternative, however, seems to be a good possibility. According to the ideal of canon law, which was formed already in the Early Middle Ages, the establishing of a church began when a bishop marked the site for the future church by placing a cross at the intended location of the altar. Thereafter he sprinkled holy water on the area for the church building and the area for the cemetery (atrium). Bertil Nilsson, who made a detailed study of the burial rights in canon and Scandinavian law, considers it likely that this act of establishment was enough to start using the cemetery for burial (Nilsson 1989:70f., 1996b:370). Of interest is that the west Norwegian Gulating Law, from the Early Middle Ages, mentions the price for consecration by a bishop in which the ground (i.e., the cemetery) is consecrated but the church is unconsecrated (Nilsson 1989:76f. with references therein). Christian Lovén (2003) has observed that when the author of Västgötalagen's Bishops Chronicles describes the achievements of various bishops, he draws a distinction between, on the one hand, the marking and consecration of church places and, on the other, the construction of the church. In Viby, outside Sigtuna, an investigation was recently made of the remains of an unfinished Romanesque church. According to Sten Tesch (2000:14, MS) only one foundation wall had been laid out, without lime mortar. This indicates that the construction of the church had been discontinued already at an early stage (possibly because the Cistercians acquired Viby in 1160 and founded a monastery there). No traces of a wooden predecessor to the unfinished church could be observed. Still, several graves were found in and near the church's foundation, among others a grave with a coffin of stone slabs that was positioned centrally in relation to the nave's foundation walls.

These examples show that, in Scandinavia, cemeteries could in fact begin to be used while the church building was still being laid out.

\footnotetext{
${ }^{24}$ That a gender division was applied at burial sites without churches is to my knowledge not evidenced in Scandinavia. In cemeteries, on the other hand, gender division was common, especially during the Early Middle Ages but in some places also during the Late Middle Ages and later. Nilsson 1989:138-144, 1994; Kieffer-Olsen 1993; Staecker 2001; H. Olsson 2002.
} 
The construction of a stone church required many years of planning, not least for the production of lime mortar for the walls. It is quite possible that graves 205-208 in the Västerhus cemetery were established during this time of planning and preparing for the church building. In that case, the planners at the time probably did not count on the church extending as far to the west as it eventually wound up doing.

Redin's third alternative explanation for why some graves were overlaid by the nave's west wall also seems plausible. The construction of Romanesque stone churches in stages, starting with the chancel, was not an uncommon procedure, and there were various reasons for it (see e.g., Lidén 1974:72f., 1983:103f.; Liebgott 1989:181). Usually the first stage consisted in building the narrow chancel, the east wall of the nave, and sections of the nave's north and south walls, at which time cavities were left in the masonry to enable bonding in the second stage. In the second stage the nave was completed. Thanks to the cavities, the seams in the walls were barely visible. ${ }^{25}$

If this was the procedure used to build Västerhus Church, we can assume that the reason for it was to complete the chancel as quickly as possible in order to consecrate the altar and the relics and begin the liturgical acts (cf. e.g., Ekroll 1998:97).$^{26}$ The procedure may also have been motivated by economic and labourpower-related factors.

In this context it should be noted that, during the excavation of the Västerhus church ruins, seams were in fact observed in the foundation of the nave's north and south walls, c. $4 \mathrm{~m}$ from the outer face of the west wall. These seams are clearly visible in Nils Lagerholm's drawings of the plan of the ruins (see fig. 2) and its facades (in ATA) in 1951. The seams are described by Bertil Berthelson (who assisted Lagerholm in the investigations of the church ruins) in the following way: "The east part of the church's foundation has a primitive construction, but its continuation in the west part of the nave shows a shift in the construction" (Berthelson 1952:297, cf. 298). According to Sven Hammarlund (who together with C. G. Blomberg led the first investigation of the church ruins in 1947), the shift in the west consisted of "even, stone slabs" which contrasted with the "rounded, uneven stones" in the foundation of the east part of the church (Hammarlund in report 1947 in ATA). The seams may be due to the circumstance that only the church's foundation was constructed in different stages, or they may

\footnotetext{
${ }^{25}$ As an example, one can mention Olavskirken in Trondheim, the ruins of which were excavated in the 1980s (Christophersen \& Walaker Nordeide 1994:97ff.). Here, the densely situated graves were found outside and very close to the church's walls, but not beneath or inside them. The church therefore must have been the first one with burial rights at the site. Analyses of the masonry have shown that the chancel was the first part completed (around the mid- $12^{\text {th }}$ century), and thereafter the nave. After that, a rebuilding of parts of the church took place. The construction of the church in stages explains why some of the oldest graves were overlaid with lime, mortar, and soapstone sherds.

${ }^{26}$ According to Berthelson's interpretation (1952:297f.), the chancel in Västerhus was given a straight east wall, whereas the smaller and less well-built apse foundation that was laid out remained unused. Cf. Hammarlund in report 1947 in ATA, Redin 2000:169f.
} 


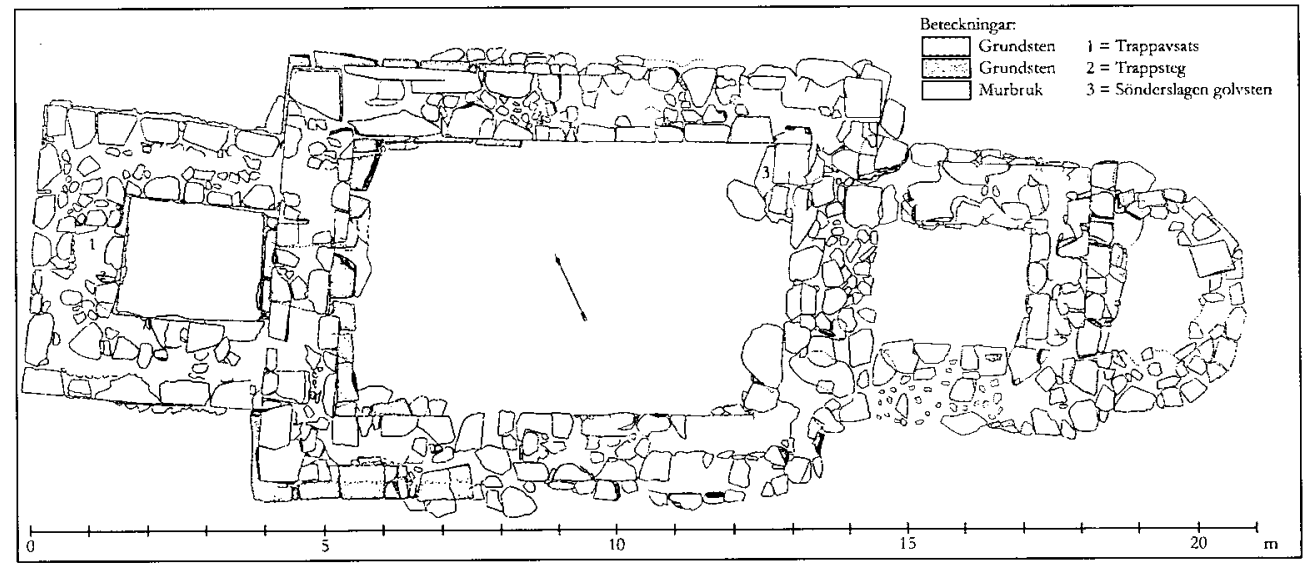

Fig. 2. Lagerholm's plan-drawing of the Västerhus church ruins, with the old west entrance to the nave secondarily walled in. ATA.

have arisen as a consequence of building the entire church in different stages. ${ }^{27}$

The most likely conclusion is that graves 205-208 were made during the planning or building stage of the stone church. ${ }^{28}$ Together with the above-discussed grave 4 , they ought to comprise some of the earliest graves in the cemetery. The stone church, in turn, can not have been built before the technique of constructing churches in stone was known and practised in the region. At what time point, then, can we assume that the first stone churches in Jämtland were built?

The very first stone churches in Scandinavia were built on royal initiative in the early towns, places that comprised political and religious centres and where wooden churches were already established (cf. Wienberg 1999:91f.). In Denmark the earliest construction of stone churches occurred in Lund and Roskilde, probably during Canute the Great's time around 1030 (according to Saxo, the Roskilde Chronicle, and archaeological dates; Cinthio 1996:15ff., 1997:119ff., 127ff.; Olsen 1961:13ff., 29ff.; Steen Jensen 1992). In Norway the earliest construction of a stone church probably took place in Trondheim during Harald Hårdråde's reign in 1045-66 (according to Snorri Sturluson; Ekroll 1997:24f., 148f.), and in Svealand probably in Sigtuna before the end of the $11^{\text {th }}$ century (according to dating on stylistic and archaeological grounds; Redelius 1975:107; Tesch 2000,

\footnotetext{
${ }^{27}$ Concerning the west tower, it is totally clear that it represents a later building phase. The walls of the west tower were namely not bonded to the nave's west wall, and they lacked the foundation shift seen in the west part of the nave (Berthelson 1952:297, 298; cf. fig. 2). Further, it is clear that the door once positioned in the nave's west entrance opened inward to the nave (cf. the design of the door posts and threshold in fig. 3 ). The door's swing shows that the entrance originally gave access from the outdoors in to the church, and not - as Berthelson has claimed - access from the church in to the west tower (cf. P. Gjærder in $K L$ 3:462; Lidén 1974:75; K. Andersson \& Hildebrand 1988:125; Karlsson 1991:317). Thus, even the entrance provides evidence that the west tower is secondary.

${ }^{28}$ There is vague and unverified information that graves were also found under the west foundation walls of the naves in the now demolished Romanesque stone churches of Alsen and Lockne in Jämtland. JämtlandsPosten 14/5 1886; Nilsson-Tannér 1935:25, cf. p. 11 and Holm 2003a:42.
} 
Fig. 3. Lagerholm's plan-drawing of the old west entrance to the nave after removal of secondary masonry. ATA.

MS). For their time period, the early stone churches were extremely advanced building projects and they demanded craftsmen from abroad. Only gradually did the preconditions develop for building churches in stone, instead of wood, in the countryside as well (Lidén 1981:10f., 46ff.; Ekroll 1997:25ff.).

The earliest stone churches in Trøndelag outside Trondheim as well as in Jämtland can

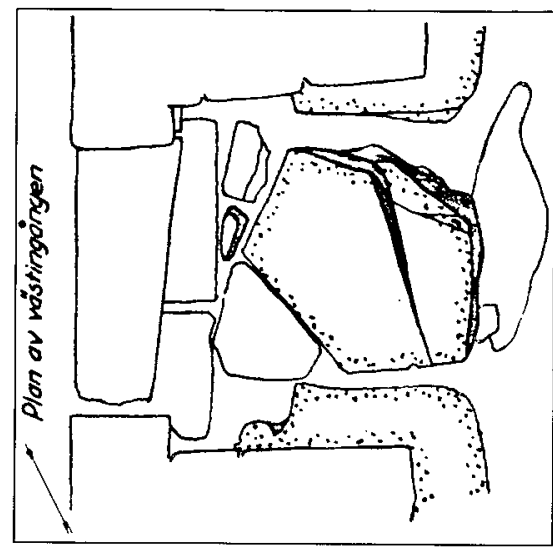
be dated on denrochronological and stylistic grounds to the decades around the mid- $12^{\text {th }}$ century. In Trøndelag the narrow chancels in these churches were often built first, before the nave (Ekroll 1998; Ekroll et al. 2000). Whether this was also the case in Jämtland is not known. The earliest dendrochronological date hitherto obtained for an original roof structure over a chancel is from Værnes Church in Trøndelag. The timber in this structure was felled in the winter of $1140-41$, which probably implies that the roof was built shortly thereafter. Since the building of a stone church required several years' labour, however, the work on the chancel of Værnes Church ought to have started around 1130-35 at the latest (Ekroll et al. 2000:226). Several other stone churches in Trøndelag as well as Jämtland apparently began to be built at the same time as, or somewhat later than, Værnes Church. This is evident from the stylistic dating of stone ornamentation, to the decades around the mid- $12^{\text {th }}$ century, on the chancels of i.a. Byneset, Levanger, and Stiklestad Churches in Trøndelag (Ekroll et al. 2000:208, 240f., 242f.; Ekroll 1998:94ff.). Further evidence is provided by dendrochronological dates to the 1160s-70s for the roofs over naves in Alstadhaug, Hustad and Selbu Churches in Trøndelag as well as Norderö Church in Jämtland (see table 2).

The earliest stone churches in Jämtland's neighbouring provinces in the east Medelpad, Ångermanland and Hälsingland - can at present not be dated with any great precision. There is, however, nothing to indicate that these stone churches are older than those in the countryside in Trøndelag (cf. Grundberg 1992:98ff.; Bonnier 1995:117f.). ${ }^{29}$

In view of the above, it is not plausible to assume that stone churches were built in Jämtland before the second quarter of the $12^{\text {th }}$ century. Thus, the year 1125 can be set as a terminus post quem for the building of Västerhus Church and the establishment of its cemetery.

\footnotetext{
${ }^{24}$ Neither is there any evidence that stone churches in rural Uppland and Gästrikland are older than the stone churches in rural Trøndelag. The oldest, dendrochronologically dated church hitherto is Boglösa Church in Uppland. The roof structure over its original nave (now the west part of a long barn church) is dated to after 1165. Bonnier 2004:38.
} 
Table 2. Dendrochronological dates of stone churches with a narrow chancel in Jämtland and Trondelag

\begin{tabular}{|c|c|c|c|c|}
\hline \multirow[t]{2}{*}{ Church } & \multicolumn{2}{|c|}{ Date of original roof structure } & \multirow{2}{*}{$\begin{array}{l}\text { Nave completed at later } \\
\text { stage than chancel }\end{array}$} & \multirow[t]{2}{*}{ Sources } \\
\hline & over chancel & over nave & & \\
\hline \multicolumn{5}{|l|}{ Jämtland } \\
\hline Hackås & c. $1151-71 ?$ & & Uncertain & Larsson 2005 \\
\hline Norderö & & $1171-72$ & Uncertain & Holm $2003 a$ \\
\hline \multicolumn{5}{|l|}{ Trøndelag } \\
\hline Alstadhaug & & $1166-67$ & Yes(?) & $\begin{array}{l}\text { Christie et al. } 1999, \text { Ekroll et al. } \\
2000\end{array}$ \\
\hline Hustad & & $1162-63$ & Yes(?) & $\begin{array}{l}\text { Christie et al. } 1999 \text {, Ekroll et al. } \\
2000\end{array}$ \\
\hline Mære & & $1198-99$ & Yes $^{1}$ & Christie et al. 1999, Lidén 1999 \\
\hline Selbu & & $1176-77$ & Uncertain & Christie et al. 1999 \\
\hline Skaun & $1278-79^{2}$ & & Yes(?) & $\begin{array}{l}\text { O. Storsletten (letter 1/12 2005), } \\
\text { Ekroll et al. } 2000\end{array}$ \\
\hline Værnes & $1140-41$ & & Yes(?) & $\begin{array}{l}\text { Christie et al. } 1999, \text { Ekroll } \\
\text { et al. } 2000^{3}\end{array}$ \\
\hline
\end{tabular}

' Stage 1 in the building of Mære Church comprised, according to Lidén (1999:4ff.), the chancel and east part of the nave, stage 2 the lower parts of the nave's south wall, and stage 3 the rest of the south wall as well as the nave's north and west walls.

${ }^{2}$ The year of felling is in Thun et al. 2004:204 incorrectly given as "1270-7l"; in the laboratory report it is listed as 1278-79 (Ola Storsletten in a letter to the author 1/12 2005).

${ }^{3}$ In the last-mentioned work, a date for the roof structure of the nave in Værnes Church has proved to be incorrect (Storsletten 2002, 2:259).

Finally, it can be noted that the plan of Västerhus Church, with a narrow chancel and a wider nave, was a type that appeared less and less in stone church construction in Sweden and Norway after c. 1250. Instead the building of one-celled barn churches became common (Nilsén 2003:265f:; Bonnier 2004:38, 40f.).

\section{HISTORICAL DATING OF VÄSTERHUS CEMETERY}

Possibilities to come to terms with the dating of the Västerhus church and cemetery are provided by a few preserved documents. In the following I will discuss them briefly; a more detailed discussion will be presented in a coming monograph (Holm MS).

The oldest document in question is a register of the land belonging to Västerhus Church, from the year 1300 (JHD I 6). In the document, it is above all clear that "the church in Västerhus" had recently acquired land in Kråksta (a neighbouring village to Västerhus) through exchange, and that Västerhus in turn had relinquished a parcel of land in Västerhus. The exchange is said to have been made in cooperation with the archbishop Nicolaus in Uppsala, which implies that it can 
have occurred at the earliest in 1295 , when Nicolaus became archbishop. ${ }^{30}$ Further, the register reveals that some land on "the lower farm" (probably in Västerhus) had been given to the church by a man named Östen Östensson as a donation for masses, that is, a donation given on condition that masses would be said for his soul after he died. Finally, the document shows that the church owned land in Tanne and Valla on the island of Frösö.

Presumably there were several phases in the process of acquiring this land. The ownership of the land in Kråksta was completely new in the year 1300. The ownership of land on "the lower farm" was not older than that the register's writer could still recall the name of the land donor. Regarding land in Tanne and Valla, as well as the land in Västerhus exchanged for that in Kråksta, the ownership was apparently old since the writer was not able or simply didn't find it necessary to say how these lands were acquired. It is possible that land was donated to the church already in connection with its consecration.

Considering the not so short history that Västerhus Church must have had behind it in the year 1300, it is hardly plausible to assume the church was built after the mid- $13^{\text {th }}$ century.

Two letters from 1494 are of great interest for the question of when the church fell out of use. One of the letters (Holm $1999 \mathrm{nr}$ 1494:A) was issued to show that Birgitta Pedersdotter gave Västerhus to Uppsala Cathedral as a donation for masses. Unfortunately this letter is known today only through a note in an old archive inventory, but a personal letter from Birgitta to her relation Master Karl Jensson on Toten (later the bishop in Hamar), written later in the same year and preserved in copies, fills in some of the gaps (JHD II 234, Holm 1999 anm. II 234). Here Birgitta notifies that, in connection with the archbishop's recent visit to Jämtland, she allotted the lands of Västerhus Church $^{31}$ to him, and she also donated her own lands in Västerhus to him.

We can see that Birgitta had the patronage rights to Västerhus Church. In cooperation with the archbishop, she had the right to manage the church's land and to allot it to Uppsala Cathedral. Since the 1470s Birgitta owned in principle all of Västerhus. Clearly, by tradition, the ownership of the lands included the patronage rights to the church. ${ }^{32}$

Uppsala Cathedral's acquisition of Västerhus as well as the lands of Västerhus Church must have implied radically altered conditions for the continued activity of the church and its existence. According to a document from 1481 (JHD II

\footnotetext{
${ }^{30}$ Note that Jämtland in the Middle Ages belonged to the Swedish church province, though politically Jämtland was part of the Norwegian realm. See Hallencreutz 1996.

${ }^{31}$ Birgitta calls these "the possessions of St. Boniface". According to a widespread and popular medieval notion, a church's land was owned by its patron saint (Hamre 2003:204). St. Boniface, together with St. Michael, was Västerhus Church's patron saint, which is known from a passage in the register from the year 1300. See further Holm MS.

${ }^{32}$ In the source material there are additional indications and evidence that Västerhus Church was a patronage church. See Holm MS.
} 
152), the church got 5 Swedish mark in rent annually for its lands, which probably helped pay for the maintenance of the church and for needs within the cult. When these lands were given to Uppsala Cathedral in 1494, Västerhus Church lost its incomes all at once. Further, the time was now past when those who owned land in Västerhus village also resided there, near the church. Those who cultivated the land from this time on were not the owners of the land but rather tenants under Uppsala Cathedral. As such, they did not have patronage rights to the church and therefore lacked possibilities to influence the activities there.

The consequences of these land transactions can be discerned in documents from the $16^{\text {th }}$ century. According to a letter of 1553 from the dean in Jämtland to King Gustav Vasa (who now controlled the estates of Uppsala Cathedral), the Västerhus lands were until recently "overgrown with forest" (NHD I, 1:190). This shows that Västerhus must have been extremely mismanaged during the first half of the $16^{\text {th }}$ century. In a letter of 1578 from the Danish-Norwegian king to the bishop in Trondheim, it is stated that in Västerhus "there used to be a chapel" (NRR 2:289f.). While letters from 1478 and 1481 (JHD II 123, 152) speak of an existing "chapel", the letter from 1578 speaks of a former "chapel". This shows that not only the lands of Västerhus but also the church had gone to ruin in the $16^{\text {th }}$ century.

Some religious services were probably still held in the church during Birgitta Pedersdotter's time as the church's patrona - the document from 1481 indicates this (cf. Nilsson 1996a:143). It is not clear whether burials were also part of the church's activities. But after Birgitta's land, her patronage rights to the church, the church's land as well as its incomes were given to the cathedral and archbishop in Uppsala in 1494, it is not likely that regular use of the church or its cemetery continued for long. If burials in the Västerhus cemetery had not ceased at an earlier date, they most likely did so at this time. Therefore I would like to set the year 1500 as an approximate terminus ante quem for when the Västerhus cemetery ceased to be used.

\section{THE VÄSTERHUS CEMETERY'S TIME OF USE: CONCLUSIONS}

In the above I have drawn the conclusions that the cemetery in Västerhus was established at the earliest around 1125 and stopped being used at the latest around 1500. The former conclusion is based on the observation that the oldest graves in the cemetery can be related stratigraphically to the stone church's planning or building stage. The latter conclusion is based on a historically known event whereby the church lost its lands and incomes and also its locally based management. The conclusions are supported by the arm positions of the deceased in the cemetery.

In addition I have maintained that it is not plausible to assume that the church and cemetery came into use later than the mid- $13^{\text {th }}$ century, on account of information in a document from 1300 listing the church's lands. This conclusion is supported to some degree by a coin from c. 1235-50 in one of the graves, as well as by the arm positions of the deceased and by the plan of the church. 
Thus the only matter left to estimate is when the cemetery, at the earliest, ceased to be used. This can be done on the basis of the following. The shift from $\mathrm{B}$ to $\mathrm{C}$ as the dominant type of arm position in the burial custom in Scandinavian cemeteries occurred in general during the period 1250-1350, to judge from the data available today. At the Västerhus cemetery, this shift must have occurred already in the first half of the cemetery's total time of use. According to Siven (2005:175), who based his estimate on available ${ }^{14} \mathrm{C}$ dates of skeletons, the total time of use is at minimum 205 years. This estimate is, of course, uncertain since it is founded on ${ }^{14} \mathrm{C}$ dates that have not been corrected for the reservoir effect, but roughly speaking it seems plausible. ${ }^{33}$ If we assume that the C-type became dominant at the earliest around 1250 , and that the cemetery thereafter was in use for at least 125 years, the conclusion must be that the cemetery fell out of use at the earliest around 1375.

In sum, we can assume that the Västerhus cemetery was established between c. 1125 and 1250 and that it ceased to be used between c. 1375 and 1500. In any event the cemetery most likely was in use for more than 200 years.

\section{VÄSTERHUS CEMETERY AND JÄMTLAND'S CHRISTIANIZATION}

We have seen how Västerhus Church and cemetery can hardly have been established before c. 1125. Is this a late date in the perspective of Jämtland? One way to shed light on this question is to examine the results from the three archaeological excavations that took place at other Romanesque stone churches in Jämtland, namely Norderö, Sundsjö and Frösö, as well as from the excavation of a Romanesque stave church in Mattmar. ${ }^{34}$

The Romanesque stone church of Norderö is still in use. Its floor was investigated in 1984, at which time five, deep trenches were opened up in the nave and one in the SE corner of the chancel (report by J. Sundström in JLM; see also Sundström 1989a, Holm 2003a:53f.). Under fill layers from the Middle Ages and more recent time was a stone floor extending throughout large parts of the nave and originating from the church's oldest phase; it consisted of flat, limestone pavestones laid out in a layer of dark soil. Under this floor was a layer of light subsoil, which had clearly visible plough marks. The church was thus built on what used to be cultivated land. Five graves (XII-XVI, all children's graves) in the nave had been dug down to the layer of light subsoil, and in these places stones were missing from the stone floor. The absent stones had probably been removed to make room for the graves, which shows that the graves must be younger than the stone floor and therefore also younger than the stone church. Otherwise no older graves were found, neither in the nave nor the chancel. Neither

\footnotetext{
${ }^{33}$ It does not seem likely that an estimate using Siven's method but based on corrected dates - if such were available - would result in a significantly shorter minimum interval. After all, the 30 uncalibrated central values of the ${ }^{14} \mathrm{C}$ series span over 430 years (table 1 ).

${ }^{34} \mathrm{Also}$ in Lit an investigation was undertaken of a Romanesque stone church (1968), but unfortunately there is no report from it. See Holm $2003 a: 36 \mathrm{ff}$.
} 
were any post-holes found, nor traces of a foundation to a possible older church. The original roof structure over the nave in Norderö Church is dendrochronologically dated to $1171-72$ (see table 2), which indicates that construction of the church must have begun at the latest around 1160-65 (cf. p. 127 above).

The Romanesque stone church of Sundsjö was abandoned around 1830, and the ruins remaining today were excavated in 1971 (report by B. Wisth in JLM; see also Holm 2003a:77f.). Five trenches were opened up, thereof one in the chancel, two in the nave, and two outside the church. Only one grave was discovered in the church, stratigraphically younger than the stone church's walls. No post-holes or traces of a foundation to a possible older church were observed. With regard to the dating of the earliest construction of stone churches in the region (see pp. $127 \mathrm{f}$ above), Sundsjö Church can hardly have been established before the year 1125. Six medieval coins, of which the oldest ( $L L$ I Bc: 4) can be dated to $\mathrm{c}$. 1190-1215, were found embedded in the remains of a wooden floor in the east part of the nave. This wooden floor is stratigraphically younger than the stone church's foundation walls. Consequently, the church can be given a terminus ante quem dating to the first half of the $13^{\text {th }}$ century.

Frösö Church, located $3 \mathrm{~km} \mathrm{SE}$ of Västerhus Church, has a nave measuring $165 \mathrm{~m}^{2}$, which can be compared with Norderö's $80 \mathrm{~m}^{2}$, Sundsjö's $42 \mathrm{~m}^{2}$, and Västerhus's $34 \mathrm{~m}^{2}$ nave. In 1984 an investigation was made of the floor in the chancel and at the front of the nave, as well as areas in the cemetery north of the nave and the west tower (Hildebrandt 1989, 1991). Older cultural layers in the west part of the chancel probably had been destroyed in later time when a deep burial chamber (grave III) and other graves were dug. ${ }^{35}$ The other investigated areas in the church, all in all approx. $23 \mathrm{~m}^{2}$, were not completely damaged by digging, however. Here only two graves were found, situated near the northeast corner of the nave. Both can be dated to c. 1300 at the earliest, one of them (XI) by means of a broken seal stamp lying near the deceased (JLM 25937:196; Hildebrandt 1989:161; Holm MS), and the other (XII) by means of two bracteates found in the fill (JLM 25937:204-205; NM 24). No post-holes or remains of a foundation to a possible older church were discerned. In the east part of the chancel, however, there were cultural layers from the Viking Age with a remarkable bone composition (incl. bear bones and elk crania), which clearly was the result of repeated sacrificial ceremonies (Hildebrandt 1989:164f.; Iregren 1989). With regard to the dating of the earliest construction of stone churches in the region (see above), Frösö Church can hardly have been established before the year 1125 . A large number of coins, the three oldest dating to the second half of the $12^{\text {th }}$ century (see table in Holm 2003a:25), were found in the northeast corner of the nave. The church can thereby be given a terminus ante quem dating to around 1200 .

${ }^{35}$ The burial chamber of brick is probably from the mid- $17^{\text {th }}$ century, and a number of coffin-graves (IV$\mathrm{X}$ ) north of it presumably date to the $1730 \mathrm{~s}-40 \mathrm{~s}$. Hildebrandt 1989:160f. Under coffin-graves VI-VIII were the remains of what I interpret as a probable burial chamber of wood, older than the coffin-graves. Only the east end of this structure was excavated. 
The stave church in Mattmar was touched upon already in the preceding ( $\mathrm{p}$. 122). It had a nave measuring about $40 \mathrm{~m}^{2}$, and was in use until the late $13^{\text {th }}, 14^{\text {th }}$, or $15^{\text {th }}$ century when it was replaced - probably due to a fire - by a larger, onecelled barn church of stone without a separate chancel. The stone church, which was expanded in the $1760 \mathrm{~s}$, is still in use today. During investigation of the stone church's floor in 1982, graves and skeletal parts from disturbed burials were found in the earth outside the walls of the stave church but inside or under the walls of the succeeding stone church. Many of these graves, including adult burials with arm-position types B (grave V) and C (XXXVII), must have been established in the stave church's cemetery. No medieval graves were found inside or under the stave church's walls. ${ }^{36}$ Neither were post-holes observed, nor traces of a foundation to a possible predecessor to the stave church. The stave church was, as said, a socalled central-mast church, a type known only from western Scandinavia and England (Ahrens 2001). Preserved central-mast churches in Nore and Uvdal, Buskerud, are dendrochronologically dated to the $1160 \mathrm{~s}$, while other types of stave churches in Norway, with sills resting on stone foundations, are dated at the earliest to the 1130s (Anker 2005:32ff.). Archaeologically known wooden churches in Norway preceding that time were, as a rule, built with dug-down, roof-supporting posts in or inside the walls (Jensenius 2001). Characteristic is that the central-mast church in Uvdal was preceded by just such a church with dug-down posts, which could be dated to the first half of the $12^{\text {th }}$ century by means of coinfinds under one of the posts (Jensenius 2001:147). Against this background, it hardly seems likely that the technique of building central-mast churches was known and applied in Jämtland before c. 1125 . The ${ }^{14} \mathrm{C}$ analyses that were made in 1982 indicate, on the other hand, that the central-mast church in Mattmar is not much younger than that time, and it was probably built at the latest around $1200 .^{37}$

In no case, thus, are there any traces of an early wooden church at the site of an archaeologically investigated, Romanesque, stone or wooden church in Jämtland. Further, no Christian graves found at these sites are older than the investigated churches. Naturally these investigations have varied in scope, but in my opinion all of them were extensive enough to conclude that, had there actually been wooden churches with cemeteries here prior to the building of the Romanesque churches, then traces of them or graves belonging to them would have been found. ${ }^{38}$ Therefore, in my view, the Romanesque stone churches of Västerhus, Norderö, Sundsjö and Frösö, as well as the stave church of Mattmar, must have been the first churches at the respective sites, and the cemeteries at these churches must have been taken into use at the earliest during the planning or building stage of the churches.

\footnotetext{
${ }^{36}$ Grave XXXXIV, E of the large post-hole, can be dated to more recent time with the help of a coin in the fill (NM9).

${ }^{37}$ Calibrated dates given in calendar years with $1 \sigma$ : two samples from the outermost, preserved wood in the remains of the central post $1040-1210$ and $1040-1220$ respectively $(2 \sigma 990-1270$ and $990-1280$ resp., St$8420,8788)$; charcoal from the bottom of the post-hole $1020-1270(2 \sigma 800-1450$, St-8736).

${ }^{38} \mathrm{Cf}$. the discussion pp. $121 \mathrm{f}$ above.
} 
As has been shown, the Västerhus cemetery and church were not established late in relation to many other cemeteries and churches in Jämtland. On the contrary, Västerhus appears to belong to a wave of church-building and cemetery-establishing in Jämtland which began during the second or third quarter of the $12^{\text {th }}$ century. ${ }^{39}$ This time point can seem late, however, with respect to the process of Christianization in Jämtland. Already around 1050-80, the Frösö rune stone was inscribed - a so-called bridge stone near the old road between Brunflo and Frösö - in which a man named Östman Gudfastsson praises himself for that he "let Christianize Jämtland". ${ }^{40}$ This is clearly a reference to the decisive event in the Christianization process, which Jan Arvid Hellström (1996:191, 199ff.) calls "the legal Christianization", i.e., the juridical anchoring of Christianity in society (cf. Skre 1998:10; Sanmark 2004:88f.). ${ }^{41}$ Östman appears to have successfully convinced Jämtland to accept the prescriptions of Christian law (cf. Brink 1996a: 178; Sandnes 1996:112f.). ${ }^{42}$ Further, we can see how the pagan custom of burying people in mounds, cairns or stone-settings within the infields of the villages and farms ceases in Jämtland already around 1025-50 (Gräslund 1996:29ff.; Grexing 1999; Welinder 2003:513ff.).

Thus in Jämtland we can discern a time gap between, on the one hand, the discontinuation of the pagan burial custom and the official Christianization, and, on the other hand, the widespread building of churches. Similar gaps in time are seen in other parts of Scandinavia as well. In large parts of Norway the pagan burial custom ceases around 950-1000, earliest in areas along the southeast and west coasts, and later in Trøndelag and the interior of east Norway (Skre 1998:8f.). The official conversion of what constituted Norway at the time occurred during the first half of the 1020s, when King Olav Haraldsson - according to information in Gulathing Law, Frostathings Law, and Snorri Sturluson - with the help of his English bishop Grimkjell instated Christian law at the Thing at Moster in Sunnhordland (Sveaas Andersen 1977:125ff.; Helle 2001:176ff.; Rindal 2004:108). ${ }^{43}$ Church-building in Norway, however, did not become widespread until the second half of the $11^{\text {th }}$ century and the beginning of the $12^{\text {th }}$ (Skre 1995:215f., 2004:247). In Denmark, graves of pagan character ceased to be established around 950-975

\footnotetext{
${ }^{39}$ For the actors behind this church construction, see Holm 2001 and MS.

${ }^{40}$ The rune stone is inscribed in A.-S. Gräslund's $(1992,1998)$ style $\operatorname{Pr} 3$. For the stone and its text see Gräslund 1996:21-28, Williams 1996.

${ }^{41} \mathrm{Cf}$. the corresponding event in Iceland in the year 999 or 1000, when according to, i.a., Ari Porgilsson's Islendingabók, the Althing decreed that those who were still not baptised should be baptised, and that henceforth it was forbidden to publicly perform sacrifices. Strömbäck 1975; Hjalti Hugason 1997; Jón Hnefill Aðalsteinsson 1999.

42 Jämtland comprised a land, i.e., a socially formed territorial unit within which, among other things, juridical cooperation took place, and possibly at this time it was not territorially incorporated in a larger realm (rike). Holm 2003b:182ff.

${ }^{43}$ The same decisive event is clearly mentioned on the stone from Kuli at Nordmøre in Norway, where it is said that, "Twelve winters had Christianity improved things (or: secured law and order) in Norway". The causeway over marshy terrain, near which the stone originally stood, has been dendrochronologically dated to the year 1034. Hallan 1966; Sveaas Andersen 1977:127; Pettersen 1990:94; Hagland 1991, 1998.
} 
(Roesdahl 1980:201; Eisenschmidt 2004:137); and at least by the 980s the large rune stone in Jelling on Jutland ( $D R$ 42) was inscribed, in which King Harald Gormsen praises himself for having "made the Danes Christian". ${ }^{44}$ However, it was not until the mid- $11^{\text {th }}$ century that church-building in Denmark was seriously under way (L. Chr. Nielsen 1991:259; Roesdahl 2004; Thaastrup-Leth 2004; cf. Eisenschmidt 2004:136ff.).

Churches and cemeteries were not, on the other hand, completely absent during the earliest Christian time in various parts of Scandinavia. At an early stage, churches were built on the initiative of the king and his bishops in connection to early towns or trading places, royal demesne, as well as estates managed by the bishops. Many of these early churches were patterned after those on the Continent and in England, serving namely as the official churches for baptism and burial of people from larger areas (Bagge 1976; Nyborg 1986:28ff.; Nilsson 1989:49ff.; Broberg 1991; Skre 1995, 2004; Rahmqvist 1996:61ff.; Helle 1997:242f.; M. Pedersen 2002; Jón Viðar Sigurðsson 2003; Sanmark 2004:102f.). In Lund and Alvastra, for instance, excavations of churches have revealed probable baptismal wells and markedly large cemeteries, dating from the end of the $10^{\text {th }}$ century and the mid- $11^{\text {th }}$ century respectively (Cinthio 1996:10; Carelli 2001; Ersgård 1996:13f.; Holmström 1999:156f.). The wooden church at Mære in Trøndelag, mentioned above (p. 122), can on reliable grounds be interpreted as such a central minster, and it probably dates from the first half of the $11^{\text {th }}$ century (Skre 2004:247). ${ }^{45}$

It seems quite plausible that one or several churches of the central minster type existed also in Jämtland during the earliest Christian time. One can hypothesize that such a church of wood stood in Brunflo, and that people from a larger area were buried in its cemetery before church construction gained momentum in Jämtland. We know that Brunflo later in the Middle Ages constituted a focal point in Jämtland for the archbishop of Uppsala. ${ }^{46}$

\section{Translated by Laura Wrang.}

\footnotetext{
${ }^{44}$ King Harald died in the 980s. Lund 1998:43; Sawyer 2002:223, 244.

${ }^{45}$ Mære Church had, according to a document from 1279 (DN II 18, RN II 211 ), demands on some of the incomes of all the churches in the upper half of Sparbyggjafylke. Mære, thus, was clearly one of the socalled fylkeskirker mentioned in the Frostathing Law. The wooden church in Mære and its successor in stone were built on a large, central estate, which at least in 1354 (DN II 326) and probably ever since the $11^{\text {th }}$ century constituted Crown lands. Sandnes 1969; Hallan 1954-56.

4h Brunflo was the site of Jämtland's largest, Romanesque, stone church - a cross-shaped church, a type unique in Jämtland but related to St. Olof in Sigtuna, the cathedral in Gamla Uppsala, and Söderala in Hälsingland. A freestanding tower was built next to the church. At Brunflo Church, before the year 1324, one third of the offerings at the altar and to the church's icons went to the archbishop in Uppsala, while the offerings in other Jämtland churches generally were kept by the churches and priests themselves in accordance with a statute from 1303. Before 1324 the archbishop was the owner of one third of Södergård (the village directly southwest of Brunflo Church). $J H D$ I 12, 27. Ahnlund 1948:509f., 54lf.; Almqvist 1984:1 10ff.; Bonnier 1995:119ff.; Vikstrand 1995; Brink 1996a:180f.
} 


\section{ACKNOWLEDGEMENTS}

I want to thank Ingmar Jansson, who was my advisor, Oystein Ekroll, Gunilla Eriksson, Ove Hemmendorff, Christian Lovén, Göran Possnert and Claes-Henric Siven, who read and commented on the text of the manuscript, Mats Anglert, Ann Catherine Bonnier, Stefan Brink, Leif Grundberg, Elisabeth Iregren, Kenneth Jonsson, Kristina Jonsson, Ingrid U. Olsson, Lars Redin, Ola Storsletten, Barbro Sundnér, Eva Wiséhn and Thorun Zachrisson, who provided valuable information and help, Sten Tesch and Anders Wikström, who let me use unpublished manuscripts, as well as Berit Wallenbergs Stiftelse, which helped fund my research.

\section{ABBREVIATIONS}

ATA The Antiquarian Topographical Archives, Stockholm

JLM County Museum of Jämtland, Östersund

KMK The Royal Coin Cabinet, Stockholm

NM The National Museum of Denmark, Copenhagen

SHM The Museum of National Antiquities, Stockholm

(For other abbreviations see below.)

\section{REFERENCES}

Ahnlund, N. 1948. Jämtlands och Härjedalens historia. 1. Intill 1537. Stockholm.

Ahrens, C. 2001. Die frühen Holzkirchen Europas. Katalog. Stuttgart.

Alexandersen, V. \& Iregren, E. 2000. Westerhus - Børnenes tænder. Hikuin. Vol. 27. Pp. 203-218.

Alkarp, M. \& Price, N. 2005. Tempel av guld eller kyrka av trä? Markradarundersökningar vid Gamla Uppsala kyrka. Fornvännen 100. Pp. 261-272.

Almqvist, B. 1984. Jämtlands medeltida kyrkor. Fornvårdaren 19. Östersund.

Andersson, K. \& Hildebrand, A. 1988. Byggnadsarkeologisk undersökning. Det murade huset. $2^{\text {nd }}$ ed. Underrättelser från Riksantikvarieämbetet och Statens historiska museer 1988:1. Stockholm.

Andersson, L. 1989. Pilgrimsmärken och vallfart. Medeltida pilgrimskultur $i$ Skandinavien. Lund Studies in Medieval Archaeology 7. Stockholm.

Andrén, A. 2000. Ad sanctos - de dödas plats under medeltiden. Hikuin. Vol. 27. Pp. 7-26.

Anker, L. 2005. Kirker i Norge. 4. Middelalder i tre-stavkirker. Oslo.

Arcini, C. \& Tagesson, G. 2005. Kroppen som materiell kultur. Gravar och människor i Linköping genom 700 år. In: Kaliff, A. \& Tagesson, G. (Eds). Liunga. Kaupinga. Kulturhistoria och arkeologi $i$ Linköpingsbygden. Riksantikvarieämbetet, Arkeologiska undersökningar, Skrifter 60. Pp. 283-319. Stockholm.

Bagge, S. 1976. Den kongelige kapellgeistlighet 1150-1319. Bergen.

Bennett, R. \& Edenheim, R. 1976. Fors kyrka. Västerrekarne härad, Södermanland. Sveriges kyrkor 168. Stockholm.

Berthelson, B. 1952. Kyrkoruinen i Västerhus. In: Arkeologiska forskningar och fynd. Studier utgivna med anledning av H. M. Konung Gustaf VI Adolfs sjuttioårsdag 11·11·1952. Pp. 295-304, 459. Stockholm.

Blohmé, M. \& Runeby, Chr. 1986. Innberetning over de arkeologiske utgravingene i Øvre Langgate 65/67, Tønsberg, 1985. 1-2. Tønsberg.

Bonnier, A. C. 1995. Medeltidskyrkornas vittnesbörd. Bebyggelsehistorisk tidskrift. Vol. 27 (1994). Pp. $105-132$.

- 2004. Medeltidens kyrkor. In: Sjöström, I. \& Sporrong, U. (Eds). Uppland. Landskapets kyrkor. Forskningsprojektet Sockenkyrkorna. Kulturarv och bebyggelsehistoria. Pp. 28-54. Stockholm. 
Brink, S. 1996a. Kristnande och kyrklig organisation i Jämtland. In: Brink. Pp. (Ed.). Jämtlands kristnande. Projektet Sveriges kristnande, Publikationer 4. Pp. 155-188. Uppsala.

- 1996b. Problemet "Jämtlands kristnande" i ett tvärvetenskapligt perspektiv. Slutbetraktelse och syntes. In:

Brink, S. (Ed.). Jämtlands kristnande. Projektet Sveriges kristnande, Publikationer 4. Pp. 201-213. Uppsala.

Broberg, A. 1990. Bönder och samhälle i statsbildningstid. En bebyggelsarkeologisk studie av agrarsamhället $i$ Norra Roden 700-1350. Upplands fornminnesförenings tidskrift 52; Rapporter från Barknåreprojektet 3. Uppsala.

- 1991. Religionsskifte och sockenbildning i Norduppland. In: Ferm, O. (Ed.). Kyrka och socken i medeltidens Sverige. Studier till Det medeltida Sverige 5. Pp. 49-79. Stockholm.

Carelli, P. 2001. Lunds äldsta kyrkogård - och förekomsten av ett senvikingatida danskt parochialsystem. Aarbøger for nordisk Oldkyndighed og Historie. 2000. Pp. 55-90.

Carlsson, D. 1999. Gârd, hamn och kyrka. En vikingatida kyrkogård i Fröjel. CCC Papers 4. Visby.

Christensen, T. \& Lynnerup, N. 2004. Kirkegården i Kongemarken. In: Lund, N. (Ed.). Kristendommen $i$ Danmark for 1050. Et symposium i Roskilde den 5.-7. februar 2003. Pp. 142-152. Roskilde.

Christie, H. 1962. Kinsarvik kirke og dens restaurering. Foreningen til norske fortidsminnesmerkers bevaring. Arbok. 1961. Pp. 47-112.

- 1966. Haralds Oslo. St. Hallvard. Vol. 44. Pp. 191-211.

Christie, H., Storsletten, O.\& Thun, T. 1999. Dendrokronologisk datering av gamle norske hus. Foreningen til norske fortidsminnesmerkers bevaring. Arbok. Vol. 153. Pp. 14I-152.

Christophersen, A. \& Walaker Nordeide, S. 1994. Kaupangen ved Nidelva. 1000 års byhistorie belyst gjennom de arkeologiske undersøkelsene på Folkebibliotekstomten i Trondheim 1973-1985. Riksantikvarens skrifter 7. Oslo.

Cinthio, M. 1996. Kyrkorna kring Kattesund. Rekonstruktionsförsök. Arkeologiska rapporter från Lund 14. Lund.

- 1997. Trinitatiskyrkan i Lund - med engelsk prägel. Hikuin. Vol. 24. Pp. 113-134.

- 2002. De första stadsborna. Medeltida gravar och människor $i$ Lund. Stockholm.

Cook, G.T., Bonsall, C., Hedges, R.E.M., Mc Sweeney, K., \& Pettitt, P.B. 2001. A freshwater diet derived ${ }^{14} \mathrm{C}$ reservoir effect at the Stone Age sites in the Iron Gates Gorge. Radiocarbon. Vol. 43. Pp. 452-460.

- 2002. Problems of dating human bones from the Iron Gates. Antiquity. Vol. 76. Pp. 77-85.

Dahlerup Koch, H. 1997. Den arkæologiske udgravning. Aarbøger for Nordisk Oldkyndighed og Historie. 1994-95. Pp. 11-191.

-2000. Rosenkranse i grave. Gravskikkens baggrund, datering og perspektiver. Hikuin. Vol. 27. Pp. 107136.

DN = Diplomatarium Norvegicum. I-. Christiania (Oslo) 1847-.

$D R=$ Jacobsen, L. \& Moltke, E. 1941-42. Danmarks Runeindskrifter. København.

Eisenschmidt, S. 2004. Kristendommens indtrængen i Syddanmark belyst ud fra gravfund i området mellem Kongeåen og Ejderen. In: Lund, N. (Ed.). Kristendommen i Danmark for 1050. Et symposium $i$ Roskilde den 5.-7. februar 2003. Pp. 123-141. Roskilde.

Ekroll, Ø. 1997. Med kleber og kalk. Norsk steinbygging i mellomalderen. Oslo.

- 1998. Steinkyrkjene i Verdølafylket. Nord-Trøndelag historielag. Arbok. Vol. 75. Pp. 84-108.

Ekroll, Ø. Stige, M. \& Havran, J. 2000. Kirker i Norge. 1. Middelalder $i$ stein. Oslo.

Engstrand, L. G. 1967. Stockholm natural radiocarbon measurements VII. Radiocarbon. Vol. 9. Pp. 387438.

Ersgård, L. 1996. Religionsskiftet som social förändring. Om tidigmedeltida gravskick i Dalarna och Östergötland. In: Engdahl, K. \& Kaliff, A. (Eds). Religion från stenålder till medeltid. Artiklar baserade på Religionsarkeologiska nätverksgruppens konferens på Lövstadbruk den l-3 ecember 1995. Riksantikvarieämbetet, Arkeologiska undersökningar, Skrifter 19. Pp. 9-17. Stockholm.

Fischer, A. \& Heinemeier, J. 2003. Freshwater reservoir effect in ${ }^{14} \mathrm{C}$ dates of food residue on pottery. Radiocarbon. Vol. 45. Pp. 449-466.

Fredén, C. 1994. Jordarterna. In: Fredén, C. (Ed.). Berg och jord. Sveriges Nationalatlas. Pp. 104-119. Höganäs. 
Gejvall, N.-G. 1960. Westerhus. Medieval Population and Church in the Light of Skeletal Remains. Kungl. Vittterhets Historie och Antikvitetsakademien, Monographs 43. Stockholm.

- 1968. Early medieval church at Westerhus in the light of C14 collagen datings. In: Res mediaevales. Ragnar Blomqvist Kal. Mai. MCMLXVIII oblata. Archaeologica Lundensia 3. Pp. 136-140. Lund.

Grexing, M. 1999. Den siste hedningen. Mitthögskolan, Östersund. [Unprinted seminar paper.]

Grundberg, L. 1992. Torsåkers medeltidskyrka och sockenbildningen i Ångermanland. In: Grundberg, L.

(Ed.). Medeltid i Ådalen. Styresholmsprojektet 1986-1992. Pp. 83-115. Härnösand.

Grundberg, L. \& Jonsson, K. 2004. Skatterna från Tuna kyrka och myntcirkulation i Norrland under $1100-$ och 1200-talen. Myntstudier 2004, 2. Pp. 6-25.

Gräslund, A.-S. 1992. Runstenar - om ornamentik och datering II. Tor 24 (1992). Pp. 177-201.

- 1996. Kristna inslag i Jämtlands vikingatid. In: Brink, S. (Ed.). Jämtlands kristnande. Projektet Sveriges kristnande, Publikationer 4. Pp. 21 -44. Uppsala.

- 1998. Ornamentiken som dateringsgrund för Upplands runstenar. In: Dybdahl, A. \& Hagland, J. R. (Eds). Innskrifter og datering. Senter for middelalderstudier, Skrifter 8. Pp. 73-91. Trondheim.

Hagland, J. R. 1991. Kulisteinen - endå ein gong. Alhaug, G., Kruken, K. \& Salvesen, H. (Eds). Heidersskrift til Nils Hallan på 65-årsdagen 13. desember 1991. Pp. 157-165. Oslo.

- 1998. Innskrifta på Kulisteinen: Ei nylesing ved hjelp av Jan O. H. Swantessons mikrokarteringsteknologi. In: Dybdahl, A. \& Hagland, J. R. (Eds). Innskrifter og datering. Senter for middelalderstudier, Skrifter 8. Pp. 129-139. Trondheim.

Hallan, N. 1954-56. Det eldste krongodset i Trøndelag. [Norsk] Historisk tidsskrift. Vol. 37. Pp. 241-265. - 1966. Kulisteinen og kristenrettsvedtaket på Mostertinget. Du mitt Nordmore. 1966. Pp. 21-28.

Hallencreutz, C. F. 1996. Jämtland i ett europeiskt perspektiv. In: Brink, S. (Ed.). Jämtlands kristnande. Projektet Sveriges kristnande, Publikationer 4. Pp. 9-20. Uppsala.

Hamre, L. 2003. Striden mellom erkebiskop Jørund og domkapitlet i Nidaros. In: Imsen. S. (Ed.). Ecclesia Nidrosiensis 1153-1537. Søkelys på Nidaroskirkens og Nidarosprovinsens historie. Senter for middelalderstudier, Skrifter 15. Pp. 187-213. Trondheim.

Hansson, A., Olsson, C., Storå, J., Welinder, S. \& Zetterström, §. 2005. Agrarkris och ödegårdar $i$ Jämtland. Östersund.

Hedvall, R. 2003. Kyrkorna i Klåstad. En presentation av ett pågående projekt. Hikuin. Vol. 30. Pp. 103-114.

Heier-Nielsen, S., Heinemeier, J., Nielsen, H. L.\& Rud, N. 1995. Recent reservoir ages for Danish fjords and marine waters. Radiocarbon. Vol. 37, 3. Pp. 875-882.

Helle, K. 1997. Det første bispedømmet på Vestlandet. In: Rindal, M. (Ed.). Selja-heilag stadi 1000 år. Pp. 240-251. Oslo.

- 2001. Gulatinget og Gulatingslova. Leikanger.

Hellström, J. A. 1996. Vägar till Sveriges kristnande. Stockholm.

Hildebrandt, M. 1989. Frösö kyrka på hednisk grund. In: Hemmendorff, O. (Ed.). Arkeologi i fjäll, skog och bygd. 2. Järnålder medeltid. Fornvårdaren 24. Pp. 153-166. Östersund.

- 1991. Rapport över arkeologiska undersökningar i och vid Frösö kyrka, Prästbordet 1:1 Frösö sn, Östersunds kn, Jämtlands län, 1984. Jämtlands läns museum, Kulturhistorisk utredning 41. Östersund.

Hjalti Hugason 1997. Att byta religion på kommando. Island som exempel på nordiskt religionsskifte. In: Dahlbäck, G. (Ed.). Kyrka-samhälle - stat. Från kristnande till etablerad kyrka. Historiallinen Arkisto 110:3. Pp. 145-166. Helsingfors.

Holm, O. 1999. Supplement till Jämtlands och Härjedalens diplomatarium. Landsarkivet i Östersund, Forskningsrapport 3. Östersund.

- 2001. Jämtarnas kyrkobyggande under medeltiden. Jämten. Vol. 95 (2002). Pp. 86-106.

-2003a. Träkyrkor, stenkyrkor, västtorn och absider. Katalog till artikeln Jämtarnas kyrkobyggande under medeltiden. Landsarkivet i Östersund, Forskningsrapport 6. Östersund.

$-2003 b$. Den norsk-svenska riksgränsens ålder och hävd. En studie av rikssamlingsprocesser och gränsbildning i mellersta Skandinavien. Collegium medievale. Vol. 16. Pp. 135-237.

- MS. Västerhus. Kyrka och högreståndsboplats. [Prel. title. Manuscript.]

Holmberg, Kj. 1995. När kungens mynt blev ailmogens mynt. En översikt över mynt, myntning och myntens roll i det svenska samhället under 1200-talet. In: Jonsson, K., Nordlind, U. \& Wiséhn, I. (Eds). Myntningen i Sverige 995-1995. Numismatiska meddelanden 40. Pp. 63-82. Stockholm. 
Holmström, M. 1999. Alvastra i statsbildningstid. In: Andersson, K., Lagerlöf, A. \& Åkerlund, A. (Eds). Forskaren i fält - en vänbok till Kristina Lamm. Riksantikvarieämbetet, Arkeologiska undersökningar, Skrifter 27. Pp. 149-160. Stockholm.

Højmark Jensen, M. 2005. Middelalderlige ringspcender i det nuvarende Danmark. Typologi og datering, fundforhold og kontekster, funktion og symbolik. Nyhedsbrevets ph.d.-afhandlinger og specialer, $\mathrm{Ny}$ række 15. Højbjerg.

Iregren, E. 1989. Under Frösö kyrka - ben från en vikingatida offerlund? In: Larsson, L. \& Wyszomirska, B. (Eds). Arkeologi och religion. Rapport från arkeologidagarna 16-18 januari 1989. University of Lund, Institute of Archaeology, Report Series 34. Pp. 119-133, Lund.

- 2002. Barndomen på Frösön. Forskning \& Framsteg. 2002, 3. Pp. 22-25.

Iregren, E., Jungner, H., Räisänen, J. \& Alexandersen, V. 2000. Dieten hos barn och vuxna i Westerhus. Data från spårämnen, kolisotoper och odontologi. Hikuin. Vol. 27. Pp. 179-202.

Iregren, E. \& Redin, L. 2000. Assemblages of children's bones in a medieval churchyard in Sweden results of epidemics, warfare, infanticide or simply, disturbed graves? In: Varela, T. A. (Ed.). Investigaciones en biodiversidad humana. Pp. 259-269. Santiago de Compostela.

Jensenius, J. 2001. Trekirkene for stavkirkene. En undersøkelse av planlegging og design av kirker for ca. år 1100. Con-text. Avhandling 6. Oslo.

$J H D=$ Jämtlands och Härjedalens diplomatarium. I-. Östersund 1943-.

Jón Hnefill Aðalsteinsson 1999. Under the Cloak. A Pagan Ritual Turning Point in the Conversion of Iceland. $2^{\text {nd }}$ ed. Reykjavík.

Jón Viðar Sigurðsson 2003. Kristninga i Norden 750-1200. Utsyn \& Innsikt. Oslo.

Jonsson, K. 1996. Gravarna vid Västerhus kapell. Människor på en medeltida kyrkogård. Magisteruppsats

(D) i arkeologi vid Stockholms universitet, vt 1996. [Unpublished seminar paper.]

- 1999. Bland barnaföderskor, spädbarn och "vuxna barn". Social och religiös kontroll speglad i gravmaterialet från Västerhus. META. Medeltidsarkeologisk tidskrift. 1999, 4. Pp. 12-35.

Jäkärä, T. 2000. Armställningar från tre finska medeltida begravningsplatser - Korois i Åbo, Liikistö i Ulfsby och Kirkkailanmäki i Hollola. META. Medeltidsarkeologisk tidskrift. 2000, 3. Pp. 56-63.

Jämtlandsposten. 1886. May 14 (No. 58); Sept. 8 (No. 107).

Karlsson, L. 1991. Sockenkyrkan - byggnadstyper och inredningskomponenter. In: Ferm, O. (Ed.). Kyrka och socken i medeltidens Sverige. Studier till Det medeltida Sverige 5. Pp. 297-320. Stockholm.

Kieffer-Olsen, J. 1993. Grav og gravskik $i$ det middelalderlige Danmark. 8 kirkegårdsudgravninger. Højbjerg.

- 2002. Gravskikken som kilde til Danmarks kristning. In: Bisgaard, L. \& Christensen, R. S. (Eds). Kristningen af Norden - et 1000-ärs jubilaum. Mindre Skrifter udg. af Center for Middelalderstudier 21. Pp. 27-35. Odense.

$K L=$ Kulturhistoriskt lexikon för nordisk medeltid från vikingatid till reformationstid. 1-21. Malmö 195677.

Lagerlöf, E. 1972. Garde kyrka. Garde ting, Gotland. Sveriges kyrkor 145. Stockholm.

Lanting, J. N. \& van der Plicht, J. 1996. Wat hebben Floris V, skelet swifterbant S2 en visotters gemeen? Palaeohistoria. Vol. 37-38. Pp. 491-519.

- 1998. Reservoir effects and apparent ${ }^{14} \mathrm{C}$-ages. The Journal of Irish Archaeology. Vol. 9. Pp. 151-165.

Larsson, R. 2005. Hackås kyrka - forskningsresultat och iakttagelser. Hackås sockenkrönika. Vol. 46 (2004). Pp. 78-85.

Lidén, H.-E. 1969. From Pagan Sanctuary to Christian Church. The Excavation of Mære Church in Trøndelag. Norwegian Archaeological Review. Vol. 2. Pp. 3-32.

- 1974. Middelalderen bygger $i$ stein. En innforing $i$ steinhugger-og murerhåndverket $i$ Norge $i$ middelalderen. Oslo, Bergen \& Tromsø.

- 1981. Middelalderens steinarkitektur i Norge. In: Berg, K. (Ed.). Norges kunsthistorie. Vol. 2. Pp. 7-125. Oslo.

- 1983. Norsk middelaldersk steinarkitektur. En generasjons bygningsarkeologiske arbeide i perioden 1950-80. Problemer og resultater. Hikuin Vol. 9. Pp. 101-112.

- 1995. De tidlige kirkene. Hvem bygget dem, hvem brukte dem og hvordan? In: Lidén, H.-E. (Ed.). Motet mellom hedendom og kristendom i Norge. Pp. 129-141. Oslo. 
- 1999. Undersøkelsene i Mære kirke. In: Hoff, A. M. \& Hommedal, A. T. (Eds). En gullgubbe. Festskrift til Hans-Emil Lidén. Pp. 1-64. Øvre Ervik.

Liebgott, N.-K. 1989. Dansk middelalderarkceologi. København.

Lilja, H., Jacobsson, B. \& Arcini, C. 2001. Svartbrödernas kyrkogård i Ahus. Arkeologisk undersökning 1996 fornlämning 23, Ahus sn, Skåne. Riksantikvarieämbetet, UV-Syd Rapport 2001:31. Malmö.

$L L=$ Lagerqvist, L. O. 1970. Svenska mynt under vikingatid och medeltid (ca 995-1521) samt gotländska mynt (ca 1140-1565). Stockholm.

Lovén, Chr. 2003. Gravar under kyrkmurar. Hikuin. Vol. 30. Pp. 115-122.

Lund, N. 1998. Harald Blåtands dod og hans begravelse i Roskilde? Roskilde.

Mollerup, L. 1999. Begravelserne ved Øm Kloster. En analyse af gravenes udsagn-datering, udformning og personsammensetning. Nyhedsbrevets ph.d.-afhandlinger og specialer, Ny række 10. Højbjerg.

Mårtensson, A. W. 1980. S:t Stefan i Lund. Ett monument ur tiden. Gamla Lund, Årsskrift 62. Lund.

$N H D=$ Norske Herredags-Dombøger: [Række I] 1-. Christiania (Oslo) 1892-.

Nielsen, J. N. 2004. Sebbersund - tidlige kirker ved Limfjorden. In: Lund, N. (Ed.). Kristendommen $i$ Danmark for 1050. Et symposium i Roskilde den 5.-7. februar 2003. Pp. 103-122. Roskilde.

Nielsen, L. Chr. 1991. Hedenskab og kristendom. Religionsskiftet afspejlet i vikingetidens grave. In: Mortensen, P. \& Rasmussen, B. M. (Eds). Hovdingesamfund og Kongemagt. Fra Stamme til Stat i Danmark 2; Jysk Arkæologisk Selskabs Skrifter 22:2. Pp. 245-267. Århus.

Nilsén, A. 2003. Focal point of the Sacred Space. The Boundary between Chancel and Nave in Swedish Rural Churches: From Romanesque to Neo-Gothic. Revised and updated ed., transl. by M. Naylor. Uppsala.

Nilsson, B. 1989. De sepulturis. Gravrätten i Corpus Iuris Canonici och i medeltida nordisk lagstiftning. Bibliotheca Thelogiae practicae, Kyrkovetenskapliga studier 44. Stockholm.

- 1994. Kvinnor, män och barn på medeltida begravningsplatser. Projektet Sveriges kristnande, Publikationer 3. Uppsala.

- 1996a. Det tidigaste kyrkobyggandet i Jämtland. In: Brink, S. (Ed.). Jämtlands kristnande. Projektet Sveriges kristnande, Publikationer 4. Pp. 117-153. Uppsala.

- 1996b. Från gravfält till kyrkogård. Förändringar och variation i gravskicket. In: Nilsson, B. (Ed.). Kristnandet i Sverige. Gamla källor och nya perspektiv. Projektet Sveriges kristnande, Publikationer 5. Pp. 349-385. Uppsala.

Nilsson-Tannér, P. 1935. Lockne kyrka genom tiderna. Några kortfattade data. In: Fädernas kyrka. Några minnesanteckningar till Lockne kyrkas återinvigning den 15 december 1935. Pp. 5-28. Lockne.

$N M=$ Ahlström, B., Brekke, B. F. \& Hemmingsson, B. 1976. Norges mynter. Stockholm.

$N R R=$ Norske Rigs-Registranter tildeels $i$ Uddrag. 1-12. Christiania 1861-91.

Nyborg, E. 1986. Kirke - sognedannelse - bebyggelse. Nogle overvejelser med udgangspunkt i et bebyggelsesprojekt for Ribeområdet. Hikuin. Vol. 12. Pp. 17-44.

Olsen, O. 1961. St. Jørgensbjærg kirke. Arkæologiske undersøgelser i murværk og gulv. Aarbøger for nordisk Oldkyndighed og Historie. 1960. Pp. 1-71.

Olsson, H. 2002. Arkeologisk undersökning av en ödekyrkogård från 1500-1600-talen. Ekshärads socken, Hagfors kommun, Värmlands län. Värmlands museum, Kulturmiljövårdsenheten, Rapport 2002:17. [Unpublished report.]

Olsson, I. U. 1983. Dating non-terrestrial materials. In: Mook, W. G. \& Waterbolk, H. T. (Eds). Proceedings of the First International Symposium ${ }^{14} \mathrm{C}$ and Archaeology. Groningen 1981. PACT 8. Pp. 277-294. Strasbourg.

- 1986. Radiometric dating. In: Berglund, B. E. (Ed.). Handbook of Holocene Palaeoecology and Palaeohydrology. Pp. 273-312. Chichester.

- 1993. The Importance of Knowing the Origin of Samples in ${ }^{14} \mathrm{C}$ Dating. In: Arwidsson, G. et al. (Eds). Sources and resources. Studies in honour of Birgit Arrhenius. PACT 38. Pp. 211-222. Rixensart.

- 1997. Kol-14 datering. Metoden och diskussion av speciella problem med isländska prov och redovisning av två serier dateringar av arkeologiskt material. The Ása G. Wright Memorial Lectures 9. Reykjavík.

- 1999. ${ }^{14} \mathrm{C}$ dates and the reservoir effect. In: van der Plicht, J. \& Punning, J.-M. (Eds). International Workshop on Isotope-Geochemical Research in the Baltic Region. Lohusalu, Estonia, March 14-16, 1996. Pp. 5-23. Groningen. 
Olsson, I. U., El-Daoushy, F. \& Vasari, Y. 1983. Säynäjälampi and the difficulties inherent in the dating of sediments in a hard-water lake. Hydrobiologia. Vol. 103. Pp. 5-14.

Pedersen, E. A. 2000. Tusen års historie i kirkegårdens dyp - fra utgravningene ved Hamar Domkirkeruin 1988-1992. Universitetets Oldsaksamling. Arbok. 1999. Pp. 177-204.

Pedersen, M. 2002. Hovedkirker i Danmark. META. Medeltidsarkeologisk tidskrift. 2002, 1. Pp. 25-48.

Pettersen, K. 1990. Nordmøres forhistorie i landskapet. Arbok for Nordmore. 1990. Pp. 77-97.

Pettersson, O. 2000. Medeltida gravar vid Hallsbergs sockenkyrka. Riksantikvarieämbetet, UV-Bergslagen, Rapport 2000:33. Stockholm.

Possnert, G. \& Söderman, M. 2001. Resultat av ${ }^{14} \mathrm{C}$-datering av ben från Jämtland. Ångströmlaboratoriet, Avd. for jonfysik, ${ }^{14} \mathrm{C}$-lab., Uppsala universitet. [Unpublished report.]

Rahmqvist, S. 1996. Sätesgârd och gods. De medeltida frälsegodsens framväxt mot bakgrund av Upplands bebyggelsehistoria. Upplands fornminnesförenings tidskrift 53. Uppsala.

Rasmusson, N. L. 1952. Rex Upsalie. Till tolkningen av en nyfunnen mynttyp från 1200-talet. In: Arkeologiska forskningar och fynd. Studier utgivna med anledning av H. M. konung Gustaf VI Adolfs sjuttioärsdag 11.11/1952. Pp. 283-294, 458-459. Stockholm.

- 1970. Kungl. Myntkabinettet, Stockholm 1969. Nordisk numismatisk årsskrift. 1970. Pp. 259-282.

Redelius, G. 1975. Sigtunastudier. Historia och byggnadskonst under äldre medeltid. Stockholm.

Redin, L. 1976. Lagmanshejdan. Ett gravfält som spegling av sociala strukturer i Skanör. Acta Archaeologica Lundensia, Series in $4^{\circ}, 10$. Bonn a. R. \& Lund.

- 2000. Arkeologiska perspektiv på Westerhus ödekyrkogård på Frösön i Jämtland. [With an appendix by O. Kyhlberg \& U. Strucke.] Hikuin. Vol. 27. Pp. 155-178, 318-319.

Reimer, P. J., Baillie, M. G. L., Bard, E., Bayliss, A. et al. 2004. IntCal04 terrestrial radiocarbon age calibration, 0-26 kyr BP. Radiocarbon. Vol. 46. Pp. 1029-1058.

Rindal, M. 2004. Dei eldste norske kristenrettane. In: Jón Viðar Sigurðsson, Myking, M. \& Rindal, M. (Eds). Religionsskiftet $i$ Norden. Brytinger mellom nordisk og europeisk kultur 800-1200 e.Kr. Senter for studier i vikingtid og nordisk middelalder, Skriftserie 6. Pp. 103-137. Oslo.

$R N=$ Regesta Norvegica. I-. Oslo 1978-.

Roesdahl, E. 1980. Danmarks vikingetid. København.

- 2004. Hvornår blev kirkerne bygget? In: Lund, N. (Ed.). Kristendommen i Danmark for 1050. Et symposium $i$ Roskilde den 5.-7. februar 2003. Pp. 201-206. Roskilde.

Rydbeck, M. 1956. Pilgrimsmärket från Fornåsa. Fornvännen. Vol. 51. Pp. 283-286.

Sandnes, J. 1969. Fylkeskirkene i Trøndelag i middelalderen. Endel notater og detaljmateriale. Arbok for Trondelag. Vol. 3. Pp. 116-136.

- 1996. Jämtene kristnet seg selv. Jämtlands kristning sett fra vest. In: Brink, S. (Ed.). Jämtlands kristnande. Projektet Sveriges kristnande, Publikationer 4. Pp. 107-116. Uppsala.

Sanmark, A. 2004. Power and Conversion. A Comparative Study of Christianization in Scandinavia. Occasional Papers in Archaeology 34. Uppsala.

Sawyer, P. 2002. Da Danmark blev Danmark. Fra ca. 700 til 1050. Gyldendal og Politikens Danmarkshistorie 3. 2. udgave. København.

Sellstedt, H., Engstrand, L. \& Gejvall, N.-G. 1967. Benvävnad som analysmaterial vid kol-14 dateringar. Fornvännen. Vol. 62. Pp. 145-154.

Serning, I. 1982. Fyndgravar och gravfynd. In: Dandanell, B. (Ed.). Tusen år på Kyrkudden. Leksands kyrka, arkeologi och byggnadshistoria. Dalarnas fornminnes- och hembygdsförbunds skrifter 25 . Pp. 71-141. Leksand.

Siven, C.-H. 2005. When was Westerhus churchyard in use? Current Swedish Archaeology. Vol. 13. Pp. $161-182$.

Sjöberg, R. 1986a. Rex Upsalie och vicarius - Erik den helige och hans ställföreträdare. Nảgot om Erikskulten och de äkta folkungarnas uppror på 1200-talet. Fornvännen. Vol. 81. Pp. 1-13.

- 1986b. Rex Upsalie-mynten och folkungaupproren 1247 och 1251. Svensk numismatisk tidskrift. 1986. Pp. 112-117.

Skov, H. 1997. Nordby - en nedlagt kirkegård fra tidlig middelalder. Viby lokalhistoriske Forening. Arsskrift. 1997. Pp. 15-20. 
Skre, D. 1986. Den bygningsarkeologiske undersøkelsen. Telemark historie. Vol. 7. Pp. 7-23.

- 1995. Kirken for sognet. Den tidligste kirkeordningen i Norge. In: Lidén, H.-E. (Ed.). Møtet mellom hedendom og kristendom i Norge. Pp. 170-233. Oslo.

- 1998. Missionary activity in early medieval Norway. Strategy, organization and the course of events. Scandinavian Journal of History. Vol. 23. Pp. 1-19.

- 2004. Kristning, misjon og konversjon i Norges vikingtid. In: Lund, N. (Ed.). Kristendommen i Danmark for 1050. Et symposium i Roskilde den 5.-7. februar 2003. Pp. 235-252. Roskilde.

$S M L=$ Sveriges mynthistoria. Landskapsinventeringen. $1-$. Stockholm 1982-.

Staecker, J. 2001. In atrio ecclesiae. Die Bestattungssitte der dörflichen und städtischen Friedhöfe im Norden. In: Auns, M. (Ed.). Lübeck Style? Novgorod Style? Baltic Rim Central Places as Arenas for Cultural Encounters and Urbanisation 1100-1400 AD. CCC Papers 5. Pp. 187-258. Visby.

Steen Jensen, J. 1992. Møntskat fra Knud den Stores eller Hardeknuds tid. In: Roesdahl, E. (Ed.). Viking og Hvidekrist. Norden og Europa 800-1200. P. 370. Kobenhavn etc.

Storsletten, O. 2002. Takene taler. Norske takstoler 1100-1350. Klassifisering og opprinnelse. 1-2. Context. Avhandling 10. Oslo.

Strömbäck, D. 1975. The Conversion of Iceland. A Survey. Transl. and annotated by P. Foote. Viking Society for Northern Research, Text Series 6. London.

Sundström, J. 1989a. Medeltidskyrka på Njords ö. In: Hemmendorff, O. (Ed.). Arkeologi i fjäll, skog och bygd. Vol. 2. Järnålder-medeltid. Fornvårdaren 24. Pp. 175-182. Östersund.

- 1989b. Stavkyrka i Mattmar. In: Hemmendorff, O. (Ed.). Arkeologi i fjäll, skog och bygd. Vol. 2. Järnåldermedeltid. Fornvårdaren 24. Pp. 145-152. Östersund.

Sveaas Andersen, P. 1977. Samlingen av Norge og kristningen av landet. 800-1130. Handbok i Norges historia 2. Oslo.

Tagesson, G., 1988. Arkeologisk undersökning samt osteologisk analys Vreta klosterkyrka och klosterområde, fornlämning 50, Vreta kloster socken, Linköpings kommun, Östergötland. Östergötlands länsmuseum, Rapport, Dnr 254/88. [Unpublished report.]

Tesch, S. 2000. Det sakrala stadsrummet. Den medeltida kyrkotopografin i Sigtuna. META. Medeltidsarkeologisk tidskrift. 2000, 1. Pp. 3-26.

- MS. På fast grund. Om det äldsta stenkyrkobyggandet i Sigtuna. Submitted to Hikuin.

Thaastrup-Leth, A. K. 2004. Trækirker i det middelalderlige Danmark indtil ca. 1100. Hvornår blev de bygget? In: Lund, N. (Ed.). Kristendommen i Danmark for 1050. Et symposium i Roskilde den 5.-7. februar 2003. Pp. 207-214. Roskilde.

Thordeman, B. 1965. Rex Upsalie. Numismatiska meddelanden. Vol. 30. Pp. 83-91.

Thun, T., Stornes, J. M., Bartolin, Th. \& Storsletten, O. 2004. Nye dendrokronologiske dateringer. Foreningen til norske fortidsminnesmerkers bevaring. Arbok. Vol. 158. Pp. 197-204.

Vikstrand, P. 1995. Det jämtländska sockennamnet Brunflo. Namn och bygd. Vol. 83. Pp. 25-37.

- 1996. Jämtland mellan Frö och Kristus. In: Brink, S. (Ed.). Jämtlands kristnande. Projektet Sveriges kristnande, Publikationer 4. Pp. 87-106. Uppsala.

Vretemark, M. 1998. Karleby kyrka. Traditionen som blev sann. Skaraborgs länsmuseum, Småskrift 5 . Skara.

Welinder, S. 2003. Christianity, politics and ethnicity in early medieval Jämtland, Mid Sweden. In: Carver, M. (Ed.). The Cross goes North. Processes of Conversion in Northern Europe, AD 300-1300. Pp. 509530. York.

Wienberg, J. 1999. From wood to stone. Church building in the County of Kalmar. In: Blomkvist, N. \& Lindquist., S.-O. (Eds). Europeans or Not? Local Level Strategies on the Baltic Rim 1100-1400 AD. CCC Papers 1. Pp. 91-114. Visby \& Kalmar.

Wikström, A., MS. Den svårfångade kronologin. Om gravstratigrafi och problem med dateringen av Sigtunas tidigmedeltida kyrkor. Submitted to Hikuin.

Williams, H. 1996. Runjämtskan på Frösöstenen och Östmans bro. In: Brink, S. (Ed.). Jämtlands kristnande. Projektet Sveriges kristnande, Publikationer 4. Pp. 45-63. Uppsala. 